\title{
Yetkili Servis Sözleşmesi ve Yetkili Servislerin Sorumluluğu
}

\author{
Onur İlhan \\ Arş. Grv., Necmettin Erbakan Üniversitesi Hukuk Fakültesi, ilhanonur70@gmail.com
}

\begin{tabular}{|c|c|}
\hline Makale Bilgileri & öz \\
\hline $\begin{array}{l}\text { Makale Geçmişi } \\
\text { Geliş: 10.07.2020 } \\
\text { Kabul: 17.09.2020 } \\
\text { Yayın: 31.12.2020 } \\
\text { Anahtar Kelimeler: } \\
\text { Yetkili servis, } \\
\text { Teknik servis, } \\
\text { Yetkili servis } \\
\text { sözleşmesi, } \\
\text { Yetkili servisin } \\
\text { sorumluluğu, } \\
\text { Satış sonrası hizmetler. }\end{array}$ & $\begin{array}{l}\text { Yetkili servisler, bir üretici veya ithalatçıya bağlı olarak yahut bağımsız bir tüzel kişilik } \\
\text { altında faaliyet gösteren, belli ürünlerin bakım, onarım ve montajıyla ilgilenen birimlerdir. } \\
\text { Günümüzde artan tüketim hızı ve ürün çeşitliliğginden dolayı, satın alınan ürünlerin zaman } \\
\text { içerisinde bakımının veya onarımının yapıllması oldukça önem arz etmektedir. Tüketiciler } \\
\text { açısından, bir ürünü satın alırken ürünün kalitesi, fiyatı sair özellikleri kadar, teknik servis } \\
\text { imkânları da göz önünde bulundurulmaktadır. Dolayssıla üretici, ithalatçı veya satıcılar } \\
\text { açısından, müşsteriye iyi bir teknik servis ağı ve imkânı sağlamak tercih edilme sebebi } \\
\text { oluşturacaktır. Ayrıca belli ürünler açısından öngörülen süreler içerisinde servis ve yedek } \\
\text { parça imkânı sunmak zorunluluğu üretici ve ithalatçılar açısından söz konusudur. Ticarî } \\
\text { hayatta aktif şekilde yer alan yetkili servisler, çoğu kez tüketiciyle doğrudan muhatap } \\
\text { olabilmekte ve tüketicinin bazı hukukî talepleriyle karşı karşıya kalabilmektedir. Yetkili } \\
\text { servisler, verdikleri hizmetle ilgili ayıplarından sorumludur. Ancak yetkili servislerin bu } \\
\text { sorumluluğu, her zaman tüketiciye karşı tek başına bir sorumluluk olarak değil, üretici veya } \\
\text { ithalatçı ile beraber bir müteselsil sorumluluk olarak meydana gelir. }\end{array}$ \\
\hline
\end{tabular}

\section{Authorized Service Contracts and Liability of Authorized Services}

\begin{tabular}{|c|c|}
\hline Article Info & ABSTRACT \\
\hline $\begin{array}{l}\text { Article History } \\
\text { Received: } \mathbf{1 0 . 0 7 . 2 0 2 0} \\
\text { Accepted: 17.09.2020 } \\
\text { Published: } \mathbf{3 1 . 1 2 . 2 0 2 0} \\
\text { Keywords: } \\
\text { Authorized service, } \\
\text { Technical service, } \\
\text { Authorized service } \\
\text { contract, } \\
\text { Liability of the } \\
\text { authorized service, } \\
\text { After sales services. }\end{array}$ & $\begin{array}{l}\text { Authorized services are units that depending a producer or importer else under operate } \\
\text { independent legal person and are concerned with maintenance, repair and installation of } \\
\text { apparent products. Nowadays it is very important that the purchased products are maintained } \\
\text { or repaired due to the increasing consumption rate and product variety. From the point of } \\
\text { the consumer, when purchasing a product, technical service opportunities are considered as } \\
\text { well as the quality, price and other features of the product. Thereby, providing a good } \\
\text { technical service network and facility to the consumer will be reason for preference in terms } \\
\text { of producer, importer or sellers. Also, it is compulsory for producer and importers to submit } \\
\text { service and spare parts within stipulated time for the certain products. Authorized services } \\
\text { who are actively in business life, can mostly direct deal with consumer and face with legal } \\
\text { request of the consumer. Authorized services are responsible, about the defects related to } \\
\text { service they provide. But, liability of authorized service, occur as joint liability with } \\
\text { producer or importer, not always singly liability against consumer. }\end{array}$ \\
\hline
\end{tabular}

Atıf/Citation: İlhan, O. "Yetkili Servis Sözleşmesi ve Yetkili Servislerin Sorumluluğu”, Necmettin Erbakan Üniversitesi Hukuk Fakültesi Dergisi, C. 3, S. 2, 2020, 233-261. 


\section{GİRIS}

Günümüzde, çağdaş endüstriyel üretim olanaklarının gelişmesi ve buna bağlı olarak tüketimin de toplum arasında yayılması, hızla üretilip satın alınan ürünlerde arıza veya herhangi bir sorunla karşılaşma oranını arttırmaktadır. Bu tip olumsuz durumlardaki mağduriyeti giderebilmek için Tüketicinin Korunması Hakkında Kanun (TKHK), Türk Borçlar Kanunu (TBK) vs. mevzuatta ayıplı ürünlere karşı sorumluluk hükümleri getirilmiştir. Hatta ayıplı ürününün sebep olduğu (refakat ettiği) birtakım zararların da nasıl karşılanacağı düzenlenmiştir. Genellikle ilk akla gelen, ayıplı bir ürünle karşılaşılldığında bu malı satan kişi olan satıcının sorumluluğudur. Satıcının ayıba karşı sorumluluğu söz konusu olmakla birlikte, ayıp sonucunda tüketici/alıcının kullanabileceği seçimlik haklardan ücretsiz onarım veya değişim gibi seçeneklerde, üretici veya ithalatçının sorumluluğu da gündeme gelmektedir (TKHK m. 11). Toplumdaki genel alg1 da, ayıplı bir ürün olduğunda ve bu sebeple bir zarar meydana geldiğinde, bu zararın üretim hatasından kaynaklandığı düşüncesiyle sorumlu olanın üretici olduğu yönündedir ${ }^{1}$. Kanundaki düzenlemelere paralel olan bu düşünce, hakkaniyete de uygun görünmektedir.

Ayıplı bir maldan ve bu malın neden olduğu zararlardan satıcı, üretici ve ithalatçının müteselsil sorumlu olduğu konusunda ihtilaf yoktur. Fakat tüketiciye karşı satış sonrası hizmetler yerine getirilirken karşılaşılan servis istasyonlarının, ayıplı maldan ve bu malın sebep olduğu zararlardan herhangi bir sorumluluğunun olup olmadığı açıkça belirtilmemiştir. Uygulamada sıklıkla karşılaşılan gerek yetkili gerek yetkisiz (bağımsız) istasyonlar, teknik konulardaki uzmanlıkları ve bilgileri nedeniyle, bir üründe görülen problem ve arızalarda ilk başvurulan yerler haline gelmiştir. Bu denli sık kullanılan servis istasyonlarının; tüketiciyle, üreticiyle veya ithalatçıla olan ilişkilerini incelemek önem arz etmektedir. Nitekim uygulamada görülen bazı davalarda, servis istasyonundaki onarım sonrasında, malın kullanımı sebebiyle oluşan zararlarda doğrudan servis istasyonlarına karşı açılan davalara rastlanmaktadır. Bu nedenle çalışmada, öncelikle satış sonrası hizmetler ve servis istasyonu kavramları, servis istasyonlarının yükümlülükleri, daha sonra yetkili servis sözleşmesinin hukukî niteliği, ardından servis istasyonları ile tüketici ve üretici ilişkileri, servis istasyonlarının verdikleri hizmetler neticesindeki sorumlulukları incelenerek bir sonuca varmaya çalışılacaktır.

\section{SATISS SONRASI HİZMETLER VE SERVİS İSTASYONU KAVRAMI}

\section{Satis Sonrasi Hizmetler}

6502 sayılı Tüketicinin Korunması Hakkında Kanun'un 58. maddesinde, satış sonrası hizmetler madde başlığı altında, üretici veya ithalatçılar için, ürettikleri veya ithal ettikleri mallarla ilgili Bakanlıkça belirlenen kullanım ömrü süreleri boyunca satış sonrası bakım ve onarım hizmetlerinin sağlanması gerektiği düzenlenmiştir. Bu hükümle beraber, üretici veya ithalatçılar için, satılan malların ayıplarının onarımı veya bakımlarıyla ilgili olarak kanunda düzenlenen iki yıllık süreden sonraki kısım için de bazı sorumluluklar doğmuştur. Böylece ithalatçı ve üreticiler, tüketiciye (alıcıya) satılan malların zaman içerisinde tamiri gerektirmesi hususunda sadece ayıptan doğan sorumluluk süresi olan iki yıllık sürede değil, Satış Sonrası Hizmetler Yönetmeliği ${ }^{2}$ gereğince ekli listede yer alan malların kullanım ömrü süreleri boyunca azami özeni göstermek ve söz konusu hizmeti sağlamakla yükümlü olacaklardır³. Zaten uygulamadaki asıl sorun da iki yıllık sürede değil bundan sonraki süreçte ortaya çıkmaktadır ve üreticiler/ ithalatçılar, söz konusu olan iki yıllık garanti sürelerinde gerekli özeni göstermekle beraber sürenin dolmasından sonra aynı özen

Aslan, İ. Yılmaz. Tüketici Hukuku Dersleri, 6. Baskı, Ekin Yayınevi, 2016, s. 134.

13.06.2014 tarih ve 29029 sayılı Resmi Gazete'de yayınlanan Satış Sonrası Hizmetler Yönetmeliği.

Aydoğdu, Murat. Tüketici Hukuku Dersleri, Adalet Yayınevi, Ankara 2015, s. 78. 
ve gayreti göstermeyebilmektedir ${ }^{4}$. Haliyle bu durum da tüketicilerin mağduriyetine yol açmaktadır. TKHK m. 56'daki garanti belgesi ve m. 58'deki satış sonrası hizmetler düzenlemeleri bu olumsuz sonuçları önlemeye yöneliktir 5 . Bu hükümlerde bahsedilen satış sonrası hizmetler olarak bakım ve onarım yapılması, sadece ayıplı bir mal söz konusu olduğu zaman uygulama alanı bulmayıp, garanti süresi içinde veya dışında ortaya çıkan arızaların tamiriyle ilgili olarak da gündeme gelebilecektir. Kanun tarafından üretici veya ithalatçılara getirilen bu zorunluluk, tüketicilere, Bakanlıkça belirlenen malların kullanım ömürleri süresince, ücreti karşılığında bakım-onarım imkânı sağlayarak bir güvence oluşturmaktadır 6 .

Üretici veya ithalatçılar, satış sonrası hizmetleri sağlamak üzere, yeterli teknik kadroya sahip yetkili servis istasyonları kurmak zorundadırlar. Bu servis istasyonlarını kendileri kurabilecekleri gibi, hali hazırda kurulu bulunan servis istasyonu veya organizasyonlarından, kendileri sorumlu olmak şartıyla faydalanabilirler (SSHY m. 5, TKHK m. 58/4). Bu şekilde yetki verilen tesis, üretici veya ithalatçıya doğrudan bağlı olmayıp fiziksel ve ekonomik bağımsızlığa sahiptir ${ }^{7}$ Üretici veya ithalatçıların söz konusu servis istasyonlarını kurabilmeleri, yönetmelikle belirlenen mallar için Bakanlıkça onaylı satış sonrası hizmet yeterlilik belgesi almaları zorunluluğuna bağlıdır (TKHK m. 58/2).

Doktrinde "satış sonrası hizmetler" kavramının biri geniş diğeri dar olmak üzere iki anlama geldiği ifade edilmiştir. Geniş anlamda satış sonrası hizmet, malın tüketiciye satılmasından sonra malla ilgili yapılan bütün işlemler ve sunulan tüm hizmetlerdir ${ }^{8}$. Dar anlamda satış sonrası hizmet ise, satış fiyatı kapsamına girmeyip ayrıca ek bir ödeme gerektiren hizmetlerdir ${ }^{9}$. Satış sonrası hizmetler; müşterilerin, ürünleri doğru ve amaca uygun kullanımlarını sağlama, arıza veya şikâyet durumlarında yedek parça ve servis hizmetlerini doğru, çabuk ve makul fiyatla sunma, müşteriyi memnun etme çabalarını ifade eder. Satış sonrası hizmetler satışın devamı olan bir olgu olarak görülürse, satıcının müşteriye, satışla beraber olanca memnuniyeti sağlama çabaları olarak ifade edilebilir ${ }^{10}$. Modern endüstri bağlamında duruma bakılırsa, ürün çeşitliliğinin ve tüketimin oldukça yüksek olduğu bu yıllarda, satıc1/ üretici/ ithalatçılar için, rakiplerinden farklı olabilmek adına müşteriyi memnun etmek oldukça önem arz etmekte ve bu durum da satış sonrası hizmetlerin daha doğru ve nitelikli verilmesini gerekli kılmaktadır ${ }^{11}$.

Satış sonrası hizmetlere örnek olarak, garanti, sigorta, bakım/ onarım hizmetleri, ürün güncellemeleri, firmaların tüketiciye sundukları çağrı merkezleri, kargo hizmeti ve farklı kanallardan iletișim olanakları verilebilir ${ }^{12}$.

\footnotetext{
$4 \quad$ Karakocalı, Ahmet. Otomotiv Sektörü Bakımından Garanti Belgesi ve Satış Sonrası Hizmetlere İlişkin Yasal Düzenlemelerin Değerlendirilmesi, Sektörel Bazda Tüketici Hukuku ve Uygulamalarl 2015-2016, Bilge Yayınevi, Ankara 2016 (Ed. TOPBAŞ, Hakan/ ÜÇIŞIK, H. Fehim), s. 146-166, s. 160.

$5 \quad$ Aslan, s. 112

6 Aslan, s. 112; Özdemir, Şerife Gül/ Sarı, Cahide Gülnur. Tüketicinin Korunması Hukuku, Danışman Yayınevi, İstanbul 2006, s. 96.

7 Dokutan, Canan. Tüketici Hukuku Bakımından Ayıplı Ifa Çerçevesinde Bayi ve Servisin Sorumluluğu, https://tez.yok.gov.tr/UlusalTezMerkezi/tezSorguSonucYeni.jsp, (Et: 16.03.2018) s. 86.

$8 \quad$ Dokutan, s. 88; Baykan, Renan. Tüketici Hukuku Mevzuata İlişkin Yorum Eleştiri Öneri, 2. Bask1, İstanbul Ticaret Odası Yayınları, 2005, s. 309.

Dokutan, s. 88; Baykan, s. 309.

Korkmaz, Sezer. "Satış Sonrası Hizmetler Ve Satış Sonrası Hizmetlerin Tüketiciler Açısından Değerlendirilmesi”, https://www.mevzuatdergisi.com/2001/06a/02.htm, (Et: 19.03.2018).

11 Akünal, Teoman. “Onarım Garantisi”, İstanbul Üniversitesi Hukuk Fakültesi Mecmuası, C. 38, S. 1-4, 1973, s. $547-570$, s. 550. 


\section{Servis İstasyonu Kavrami}

\section{Genel Olarak}

Kavram olarak "servis" kelimesi, sözlükte ${ }^{13}$; "otomobil, beyaz eşya vb. ürünlerin bakım ve onarımlarının yapıldiğg yer" şeklinde tanımlanmıştır. Çalışmanın konusunu oluşturan servis istasyonları da belli ürünlerle ilgili teknik bilgi ve destek hizmeti sunarak bakım ve onarım yapan yerleri ifade etmektedir. Günümüzde endüstriyel ürünlerin çeşitliliğinin artması ve bu ürünler ile ilgili teknik bilginin önem kazanmasından dolayı profesyonel anlamda servis istasyonu olarak hizmet veren yerler, ekonomik düzen içerisinde önemli bir yere sahiptir. Bu servis istasyonlarının bazıları, üretici veya ithalatçılara bağlı şekilde çalışırken bir kısmı da herhangi bir yerle anlaşması olmadan bağımsız şekilde faaliyet göstermektedir. Aşağıda bu iki farklı tür istasyonlar tanımlanarak çalışmanın devamında da konuyla ilgili olarak yeri geldikçe karşılaştırmalı olarak incelenecektir.

\section{Yetkili Servis}

Satış Sonrası Hizmetler Yönetmeliğinin m. 4/1-m bendine göre; "Yetkili servis istasyonu, üretici veya ithalatçıların ürettikleri veya ithal ettikleri mallar için; kullanım ömürleri süresince satış sonrası montaj, bakım ve onarım hizmetlerini yürütmek üzere, kendileri tarafindan veya aralarındaki sözleşme uyarınca, bu amaçla yetki verilen gerçek veya tüzel kişiler tarafindan kurulan ya da kurulmuş bulunan tesisleri" ifade eder. Maddedeki ifadeden de anlaşıldığı üzere, satış sonrası hizmetler kapsamında, üretici veya ithalatçının sorumlu olduğu bu konuda, ya bizzat kendileri tarafindan söz konusu hizmetler yerine getirilecek ya da bu amaçla herhangi bir servis istasyonuna sözleşme vasıtasıyla yetki verilecektir. Yetki verilen servis istasyonu yeni kurulabileceği gibi önceden bu tip hizmetleri sunan bir servis istasyonu da söz konusu olabilir. Her iki durumda da yetkili servisin sunduğu hizmet ve yaptığı işle ilgili olarak, üretici/ ithalatçının kontrolünün bulunması zorunludur. Doktrinde, üretici veya ithalatçının kendisinin kurduğu servise "iç servis", satış sonrası hizmetlerin sunulması için başka servislerle anlaşma yapılması hâlinde "bağımlı servis istasyonu (anlaşmalı özel servis)" şeklinde bir adlandırma ileri sürülmüştür ${ }^{14}$.

Üretici/ ithalatçı, salt servis istasyonunu kurarak veya bir servise yetki vererek sorumluluktan kurtulamaz. Bu süreçte devamlı servis istasyonunu izlemek, denetlemek ve görülen eksiklikleri gidermek durumundadır ${ }^{15}$. Çünkü yetkili servislerin ayrı bir tüzel kişiliği bulunsa dahi, faaliyetlerinden dolayı üretici veya ithalatçıların müteselsil sorumluluğu bulunmaktadır (SSHY m. 14). Bu sorumlulukla ilgili olarak yetkili servisler ve üretici/ ithalatçı arasındaki ilişki ilerleyen bölümlerde incelenecektir ${ }^{16}$.

\section{Bağımsız (Özel) Servis}

Bağımsız (özel) servis istasyonları ise, üretici veya ithalatçıla aralarında herhangi bir anlaşma/ sözleşme bulunmayan ve bu nedenle yetkilendirilmemiş, faaliyetlerini üretici/ ithalatçının organizasyonundan ayrı yürüten servislerdir. Bağımsız servisler, yetkili servislerin bir alternatifini oluşturur ${ }^{17}$. Bu tip bağımsız servis istasyonları herhangi bir üretici veya ithalatçıyla ilişki içerisinde olmadığından faaliyetlerinden dolayı da kendileri sorumlu olacaktır. Ancak üretici veya ithalatçılar bu konuda bağımsız servis istasyonuna herhangi bir yönlendirme yapmışlar ise sorumlulukları söz konusu olabilecektir ${ }^{18}$.

\footnotetext{
13 http: // www. tdk. Gov. tr/ index. php? option= com_ bts\&arama=kelime\&guid=TDK.GTS. 5aabb1d9685210. 78408315

Aydoğdu, s. 78.

Dokutan, s. 87.

Bkz. V, A.

Uyumaz, Alper. Yetkili Servis Sözleşmesi, Oniki Levha Yayınları, İstanbul 2018, s. 25.

Aydoğdu, s. 79.
} 
Satış sonrası hizmetler, yetkili servis istasyonları vasıtasıyla verilebileceği gibi, bağımsız servis istasyonları aracılığı ile de verilebilir. Ancak, Yönetmelik’te, bağımsız servis istasyonlarının kuruluşu ve işleyişine ilişkin esaslar düzenlenmemiştir ${ }^{19}$. Bu hâlde, yetkili servis istasyonlarına uygulanacak hükümler, niteliğine uygun düştüğü oranda bağımsız servis istasyonlarına da uygulanmalıdır. Fakat, bağımsız servis istasyonlarının kuruluş ve işleyişine yönelik hükümlerin getirilmesi daha uygun olacaktır.

\section{YETKILII SERVIS İSTASYONLARININ KURULUŞU VE YÜKÜMLÜLÜKLERİ}

\section{Servis İstasyonlarinin Kuruluşu}

Servis istasyonlarını kurma yükümlülügü yukarıda da bahsedildiği gibi üretici veya ithalatçıya ait bir yükümlülüktür ${ }^{20}$. TKHK kapsamında tüketicinin seçimlik haklarından biri olan satılanın ücretsiz onarımı, satıcıdan talep edilebileceği gibi müteselsil sorumluluktan dolayı üretici veya ithalatçıdan da talep edilebilir (TKHK m. 11/1 ve 2). Buradaki gibi talep satıcıya yöneltildiğinde onarım masrafları satıcıya ait olmakla beraber onarım fiilinin teknik bilgi ve ekipmanı gerektirmesi nedeniyle yine bir servis istasyonunun varlığına ihtiyaç duyulur. Bu nedenle kanun onarım ve bakım hizmetleri için bir servis istasyonunun kurulmasını veya yetkilendirilmesini zorunlu kılmıştır. Fakat bu zorunluluk satıcı için değil ürünü meydana getiren üretici veya yurt dışından ithal eden ithalatçıya yüklenmiştir. Servis istasyonlarının kurulması belli bir prosedüre bağlanmıştır. Üretici veya ithalatçıların servis istasyonu kurabilmeleri, yönetmelikle belirlenen mallar için Bakanlıkça onaylı satış sonrası hizmet yeterlilik belgesi almalarına bağlıdır (TKHK m. 58/2). Yönetmelikteki ekli listede yer almayan mallar veya bu listede yer alıp da servis istasyonu kurulması gerekmeyen mallar için ise söz konusu belge düzenlenmez ${ }^{21}$ (SSHY m.6/1). Satış sonrası hizmet yeterlilik belgelerinin geçerlilik süresi ise iki yıldır (SSHY m.7/1). Belgenin süresi dolmadan önce yenilenmesi gerekmektedir (SSHY m. 7/1) ${ }^{22}$.

\section{Servis İstasyonlarinin Yükümlüllükleri}

\section{Onarım ve Bakım Yükümlülü̈̆̈̈̈}

Servis istasyonlarının, kuruluş amaçları düşünüldüğünde, en doğal yükümlülüklerinin bakım ve onarım yükümlülüğü olduğu ifade edilebilir. Onarım (tamir) kavramı sözlükte, "bozulmuş bir aygıt, makine ya da nesneyi; eskimiş bir yapı, döşem vb. düzeltip, yararl ve yeniden işler duruma getirme, yenileştirme"

19 Karakocalı, Ahmet. Tüketici Hukuku Davalarl, Teori-Uygulama, (Ed. Şahin Mccarthy, Oya/ Dinç, Mutlu), Seçkin Yayıncılık, Ankara 2017, s. 722.

20 Bkz. I, A.

21 Servis istasyonlarının kuruluşu hakkında ayrıntılar için ilgili yönetmelik maddesi;

"Başvuru ve izin

MADDE 6 - (1) Üretici veya ithalatçıların, ekli listede yer alan mallar için Bakanlıkça onaylı satış sonrası hizmet yeterlilik belgesi alması zorunludur. Bu Yönetmeliğin ekli listesinde yer alan ancak servis istasyonu gerekmeyen mallar için satış sonrası hizmet yeterlilik belgesi düzenlenmez.

(2) Satış sonrası hizmet yeterlilik belgesine yönelik başvurular, Bakanlığın internet sayfasında, elektronik imza ile yapılır ve elektronik imza ile onaylanır.

(3) Başvuru ile ilgili hususlar Bakanlığın internet sayfasında ilan edilir.

(4) Başvuru üzerine Genel Müdürlükçe, Kanun ve bu Yönetmeliğe uygunluk açısından gerekli incelemeler yapılarak yeterli görülenlere satış sonrası hizmet yeterlilik belgesi verilir.

(5) Genel Müdürlük, başvuruları değerlendirirken gerek duyması halinde tüketicilerin sağlık ve güvenliği ile ekonomik çıkarlarını korumak amacıyla; belgelendirme yapılacak ürünle ilgili olarak, gerekli incelemeleri yapmaya veya yaptırmaya yetkili olup, daha önce onaylanmış kuruluşlardan alınacak raporları ve ürünle ilgili olarak diğer kamu kurum ve kuruluşları tarafından verilen belgeleri de dikkate alabilir”.

2212 Şubat 2020 tarih ve 31037 sayılı Satış Sonrası Hizmetler Yönetmeliğinde Değişiklik Yapılmasına Dair Yönetmelik'in yayınlanmasından önce, iki yıllık süre dolduktan sonra belgenin yenilenmesi için başvurulabilmekteydi. 
olarak tanımlanmıştır ${ }^{23}$. Hukukî anlamda onarım kavramına bakıldığında ise, "alıcının, ayıba karşı tekeffül dolayısıyla sahip olduğu kanuni ayıba karşı tekeffül hükümlerinin yerine getirilmesine engel olunması için, satılmış bir maldaki ayıpların giderilmesidir" şeklinde tanım yapıldığı görülmektedir ${ }^{24}$. Onarım borcu niteliği itibarıyla bir iş görme borcudur bu nedenle edim türleri açısından olumlu ve yapma edimi olarak nitelendirilir. Çünkü olumlu edimlerde borçlu, bir faaliyette bulunmak, böylece bir işi yapmak veya bir şeyi vermek zorundadır ${ }^{25}$. Onarım borcu bir iş görme borcu olduğundan, bu borcun ifası için teknik bilgiye sahip personel çalıştırılması, malın değişmesi gereken parçaları için yedek parça bulundurulması, karmaşık ve zor tamir işleri için sürekli kullanılması gerekebilecek alet ve ekipmana sahip olunması gerekebilir ${ }^{26}$.

Onarım borcu, TKHK m. 11/1-c'de yer alır ve ayıplı bir mal söz konusuysa, tüketicinin başvurabileceği seçimlik haklardan biridir. Buna göre, onarım seçimlik hakkının kullanılabilmesi, ancak bunun aşırı bir masrafı gerektirmemesine bağlıdır. Onarım faaliyetiyle ilgili yapılacak tüm masraflardan satıcı sorumludur. Tüketici, bu hakkını satıcıya karşı kullanabileceği gibi üretici veya ithalatçıya karşı da kullanabilir. Bu konuda satıcı, üretici ve ithalatçı müteselsilen sorumludur. (TKHK m. 11/2).

Ayıplı malın onarımı, TKHK'daki düzenlemeyle paralel şekilde TBK'nın 227. maddesinde de bulunmaktadır. Buradaki hüküm de satış sözleşmelerinde ayıplı çıkan malın akıbetinin ne olacağıyla ilgilidir ve TKHK'ya benzer şekilde alıcıya bazı seçimlik haklar tanımıştır (TBK m. 227). Bu düzenlemenin TKHK m. 11'den farkı, alıcının tüketici olmadığı durumlarda uygulama alanı bulabilmesidir. Aynı zamanda bu hüküm, satış sözleşmesindeki ayıptan doğan sorumluluk durumuyla ilgilidir. Eser sözleşmelerindeki ayıptan doğan sorumluluk hükümleri ise TBK m. 475 'te düzenlenmiştir. Bu hükümde de, işsahibinin, eserdeki ayıbın giderilmesi yönünde yükleniciye karşı ileri sürebileceği onarım seçimlik hakkı bulunmaktadır. Bu düzenlemeye benzer şekilde TKHK $\mathrm{m}$. 15'te de ayıplı hizmet sonucu tüketicinin seçimlik haklarına değinilmiş ve bunların arasında onarım hakkının da bulunduğu belirtilmiştir ${ }^{27}$.

Onarım hakkıyla ilgili değinilmesi gereken bir diğer önemli husus, onarım hakkının sadece ayıptan doğan sorumluluk durumlarında söz konusu olmayıp, garanti süresi içinde veya dışında, malın kullanım ömrü süresince mevcut olması gereken bir hak olduğudur. Garanti süresi içinde, maldaki bir ayıp veya arıza nedeniyle onarım talep edilmişse, bu talep ücretsiz olarak yerine getirilecektir (GBY m. 8) ${ }^{28}$. Garanti süresinin dolduğu hallerde, malın kullanım ömrü süresi devam ediyorsa, yine servis hizmeti sağlanmak zorunda olduğundan, tüketici, malın onarımı imkânından faydalanabilecektir. Bu durumun garanti süresi

23 http://www. tdk. gov. tr/index. php? option= com_bts\& arama= kelime\& guid= TDK. GTS. 5ab24eb9d01aa6. 93443437, Et: 31.05.2020.

24 Arbek, Ömer. Satım Konusu Ayıplı Malın Tamir Edilmesi, Yetkin Yayınları, Ankara 2005, s. 45.

25 Eren, Fikret. Borçlar Hukuku Genel Hükümler, 23. Baskı, Yetkin Yayınları, Ankara 2018, s. 102; Kocayusufpaşaoğlu, Necip. Borçlar Hukukuna Giriş, Hukuki Işslem, Sözleşme, C. 1, 7. Tı1pkı Baskı, Filiz Kitabevi, İstanbul 2017, s. 35; Tekinay, Selahattin Sulhi/ Akman, Serhat/ Burcuoğlu, Haluk/ Altop, Atilla. Borçlar Hukuku Genel Hükümler, 7. Baskı, Filiz Kitabevi, İstanbul 1993, s. 9; Akınc1, Şahin. Borçlar Hukuku Bilgisi, 10. Baskı, Sayram Yayınları, Konya 2017, s. 24; Hatemi, Hüseyin/ Gökyayla, Emre. Borçlar Hukuku Genel Bölüm, 3. Bask1, Vedat Kitapçılık, İstanbul 2015, s. 8; Kılıçoğlu, Ahmet M. Borçlar Hukuku (Genel Hükümler), 22. Bask1, Turhan Kitabevi, Ankara 2018, s. 6; Antalya, O. Gökhan. Borçlar Hukuku Genel Hükümler, C. 1, Legal Yayınevi, İstanbul 2018, s. 50.

26 Aslan, Bayram. "Onarım Borcunun İfa Edilmesi”, Selçuk Üniversitesi Hukuk Fakültesi Dergisi, C.25, S.1, 2017, s. 294.

27 Hizmet kavramı, TKHK m.3/1-d'ye göre, “bir ücret veya menfaat karşılığında yapılan ya da yapılması taahhüt edilen mal sağlama dışındaki her türlü tüketici işleminin konusunu" ifade etmektedir.

Uygulamada, malın onarımıyla ilgili olarak farklı kavram ve nitelendirmelerle tüketiciden bedel talep edildiği görülmektedir. Ancak, bu gibi hallerde de tüketiciden ücret talep edilemez. Bununla birlikte, malzeme masrafı, işçilik masrafı gibi yapılan çeşitli harcamaların tüketiciden talep edilmesi mümkün değildir. Ücretsiz onarım kavramının geniş olarak anlaşılması gerektiği yönünde bkz., Arbek, s. 204. 
içindeki onarımlardan farkı, ücrete tabi olmasıdı2 ${ }^{29}$. Malın garanti süresi dışında meydana gelen arızalarda, servis istasyonları tarafından verilen bakım-onarım hizmetleriyle ilgili, aynı arıza bir yıl içinde tekrar ederse, bu hâlde tüketiciden herhangi bir ücret talep edilemeyecektir. Tüketicinin malı, kullanım kılavuzundaki hususlara aykırı kullanması hali bunun dışındadır (SSHY m. 10/6).

Onarım hakkının kullanılması ile beraber servis istasyonlarına gelen malların, orada tamir ve bakım için kalması gereken süreler sınırsız değildir. TKHK m. 58/3'e göre bu konuda tamir süresinin üst sınırı yönetmeliğe bakılarak belirlenecektir. Söz konusu yönetmelik olan SSHY'nin ek listesinde belirli ürün çeşitleri için azami tamir süreleri belirlenmiştir. Bu süre birkaç istisnai ürün dışında yirmi iş günüdür ${ }^{30}$. Yönetmelikle, bu şekilde üst süre sınırının belirlenmesi, servis istasyonlarının keyfi davranmaları ihtimalinin önüne geçerek hizmetin savsaklanmasını engelleyecek ve müşteri mağduriyetini bu anlamda giderecektir ${ }^{31}$. Sürenin başlangıç tarihi, ürünün garanti kapsamında olup olmamasına göre değişecektir. Bu süre, garanti süresi içerisinde mala ilişkin arızanın yetkili servis istasyonuna veya satıcıya bildirimi tarihinde, garanti süresi dışında ise malın yetkili servis istasyonuna teslim tarihinden itibaren başlar (SSHY m. 10/4). Görüldüğü gibi malın garanti kapsamında olup olmamasının tamir süresine bir etkisi yokken, tamir süresinin başlangıcı açısından önemli bir etkisi söz konusudur. Belirtilen süre içerisinde ücretsiz onarım talebi yerine getirilmezse, tüketici diğer seçimlik haklarına başvurabilir ${ }^{32}$.

Onarım hakkı kapsamında, servis istasyonları, tüketicinin bu hakkının gereği olarak, söz konusu malı ücretsiz olarak tamir etmek durumundadır. Bu tamir ile ilgili masraflara da TKHK m. 11 ve TBK m. 227 gereği satıcı (talep yöneltildiyse üretici veya ithalatçı) katlanmak zorundadır. Bu masraflara örnek olarak, posta ve nakliye masrafları, bilirkişi ücreti, vekâlet ücreti gibi mahkeme masrafları verilebilir. Ayrıca tüketici, yapmadığında malın ziyanına sebep olacak masraflar (zorunlu masraf), bir zorunluluk olmasa bile yarar elde etmek amacıyla yapılan masraflar (faydalı masraf) ve zevk amaçlı yapılan (lüks masraf) masrafları da satıcıdan talep edebilir. Tabi tüketicinin maldaki ayıbı öğrendikten sonra yaptığı lüks masrafları talep edebilmesi mümkün olmayıp, bunları ancak mala zarar vermeden söküp alabilmesi mümkündür ${ }^{33}$. Peki bu masrafların çok fazla olması durumunda ne olacaktır? Satıcı (veya üretici/ithalatçı), masraflar ne kadar yüksek olursa olsun katlanmak zorunda mıdır? Bununla ilgili olarak TKHK m. 11 ve TBK m. 227 düzenlenmelerine göre, ücretsiz onarım hakkı ancak bu durumun aşırı bir masrafı gerektirmemesi hâlinde mümkündür. İki kanunda da paralel şekilde düzenlenen "aşırı bir masrafı gerektirmeme" halinin tespitinde kullanılacak ölçütler belirtilmemiştir. Her şeyden önce, onarımın aşırı bir masrafı gerektirmeme hali kanunda düzenlenmemiş olsaydı bile, TMK m. 2'de düzenlenen dürüstlük ilkesi gereği, hakların kullanılmasının üst sınırını hakkın kötüye kullanılması yasağı oluşturacağından, onarım masrafları aşırı olursa bu hak kullanılamayıp diğer seçimlik haklara gitmek gerekecektir. Hali hazırda iki kanunda da aşırı bir masrafı gerektirmeme durumu söz konusu olup ve aşırı masraftan kastın ne olduğu da belirtilmemiş olduğundan doktrinde yer alan bazı kıstasları göz önüne almak gerekir. Bu kıstaslardan biri, ayıplı malın tamir edilmesi için yapılması gereken masraflar ile malın satış fiyatının karşılaştırılmasıdır. Eğer tamir için gereken masraflar malın satış fiyatını geçiyorsa, tamirin aşırı bir masrafı gerektirdiği söylenebilir. Bir diğer husus, malın tamiri için yapılan masraflarla tüketicinin malın tamiriyle sağlayacağ 1 yarar arasında bir dengesizlik söz konusuysa, bu hâlde de tamir masrafının aşırılığından bahsedilebilir ${ }^{34}$. Fakat ayıplı malın tamir edilmesi için yapılan masraflar, satıcının sözleşmeden dönme, bedel indirimi veya ayıpsız misliyle değiştirme seçimlik haklarına nazaran daha fazla zarara uğramasına sebebiyet veriyor olsa

29 Dokutan, s. 94; Göçer, Ahmet Alpaslan. Garanti Belgeleri, http: // acikerisim. selcuk. edu. tr: 8080/ xmlui/ bitstream/ handle/123456789/5610/337689.pdf? sequence=1\& isAllowed=y, (Et: 31.05.2020), s. 233.

İstisnaî olarak azami tamir süresi, binek otomobil ve kamyonetlerde otuz iş günüdür.

Dokutan, s. 94.

Özel, Çağlar. Tüketicinin Korunması Hukuku, 3. Baskı, Seçkin Yayınevi, Ankara 2016, s. 123.

Özel, s. 123.

Arbek, s. 179. 
bile, bu tamir masrafının aşırı olduğu anlamına gelmez. Hatta, satıcının tamir için yaptığı masraflardan dolayı bu satıştan hiç kâr edememesi veya zarar etmesi, tamir masrafının aşırı olarak kabul edilmesini gerektirmez $^{35}$. Son olarak belirtilmelidir ki, tamir masraflarının aşırılığı belirlemesi yapılırken, her somut olay açısından ayrı ayrı değerlendirme yapılıp bir sonuca varılmalıdır ${ }^{36}$.

Onarım yeri, üretici veya ithalatçıların bu yükümlülüklerini yetkili servis istasyonları aracılığıyla yerine getireceği düşünüldüğünde, tüketicinin bulunduğu yerdeki servis istasyonudur. Zira SSHY'nin 10. maddesinden anlaşıldığ üzere, öncelikle tüketicinin bulunduğu yerdeki servis istasyonu sorumlu olacak, eğer bu yerde istasyon yok ise tüketiciye en yakın yerdeki servis istasyonu sorumlu tutulacaktır. Tüketiciye en yakın servis istasyonunda hizmet verilemiyorsa, malın firma merkezi veya diğer bir istasyona gönderilmesiyle ilgili tüketiciden herhangi bir isim altında ulaşım gideri talep edilemeyecektir (SSHY m. 10/2). Bu hüküm tüketici lehine yerinde bir düzenleme olup, uygulamada bir sorun olarak karş1laş1lan, servis istasyonlarının, daha yetkili veya donanımlı oldukları gerekçesiyle onarım için malı uzak istasyonlara göndermek istemeleri ve bunun masrafını tüketiciye yansıtabilmelerini engellemiştir ${ }^{37}$.

\section{Servis Fişi Düzenleme Yükümlüllüğü}

Servis fişi, servis istasyonlarının, malla ilgili arıza tespitleri ve buna bağlı yapılan onarım işlemlerinin gösterildiği, eğer onarım garanti süresi dışında gerçekleşmişse buna ilişkin ücreti, servis istasyonuyla ilgili bilgileri içeren ve bu istasyonlar tarafindan düzenlenip tüketiciye verilmesi zorunlu olan bir belgedir ${ }^{38}$. Bu belgenin içeriğinde yer alması gerekenlerden biri de, onarımdan sonraki bir yıl içerisinde aynı arızanın tekrar ortaya çıkması hâlinde yapılacak olan tamir sonucunda, tüketiciden yeniden ücret talep edilemeyeceğidir. Fakat bu durum garanti süresi kapsamı dışında kalmış olan ürünler için geçerli olup tüketicinin malı kullanma kılavuzuna uygun kullandığg hallere ilişkindir. Garanti süresi içinde olan ürünler için ise zaten ücretsiz onarım söz konusu olduğundan bu hususta bir problem oluşmamaktadır ${ }^{39}$.

\section{Teslim Alma Belgesi Düzenleme Yükümlülü̈̆̈̈}

Satış Sonrası Hizmetler Yönetmeliği m. 11'e göre servis istasyonları, kargoyla gönderilen mallar hariç olmak üzere, kendilerine teslim edilen veya kendileri tarafından teslim alınan arızalı mallar ile ilgili olarak söz konusu malın teslim alındığına dair belli bazı bilgileri içeren bir teslim alma belgesi düzenlemek zorundadır ${ }^{40}$. Buna göre teslim alma belgesi, servis istasyonlarına gelen mallarla ilgili gerekli işlemlere

Arbek, s. 180; Aslan, s. 326

Aynı yönde bkz., Dokutan, s. 97.

Dokutan, s. 95; Aslan, s. 308; Çınar Ural, Nihal. Tüketicinin Korunması Hakkında Kanun'a Göre Ayıba Karşı Tekeffül, https://tez.yok.gov.tr/UlusalTezMerkezi/tezSorguSonucYeni. jsp, (Et: 04.04.2018).

SSHY m. 11/2'ye göre, "Servis istasyonlarının, tüketicilere teslim edilen mallarla ilgili olarak aşağıdaki bilgileri içeren servis fişini tekemmül ettirmesi ve tüketicilere vermesi zorunludur:

a) Servis istasyonunun unvan, adres, telefon, faks ve diğer erişim bilgileri,

b) Malın tüketiciye teslim tarihi,

c) Malın arızasına ve yapılan işlemlere ilişkin bilgi,

ç) Garanti kapsamı dışında ise ücreti,

d) Servis istasyonu yetkilisinin imzası,

e) Bu Yönetmeliğin 10 uncu maddesinde yer alan, servis istasyonlarının sorumluluklarını gösterir hususlar,

f) Kargo ile teslim alınan ürünler haricinde, tüketicinin adı, soyadı, adresi ve telefonu ile imzası."'

Servis fişi ve teslim alma belgesi düzenleme yükümlülüğü, hem yetkili servis istasyonları hem de bağımsız (özel) servis istasyonları için söz konusudur. Bkz., KARAKOCALI, Tüketici, s. 723.

Dokutan, s. 93; Özdemir/ Sarı, s. 98.

Servis istasyonlarınca düzenlenecek belgeler

MADDE 11 - (1) Servis istasyonlarının, kendilerine kargo ile gönderilen arızalı mallar hariç olmak üzere, kendilerine teslim edilen veya kendileri tarafından teslim alınan arızalı mallar ile ilgili olarak malın teslim alındığına dair aşağıdaki bilgileri içeren bir belge düzenlemesi zorunludur:

a) Malı teslim edenin ad1, soyadı ve imzası, 
başlamadan önce, servis tarafından düzenlenmesi yönetmelikte öngörülen bir belgedir. Bu belgenin içeriğinde bulunması gereken teslim eden ve teslim alan kişilerin ad-soyad ve imzaları, malla ilgili sorunun ne olduğuna dair açıklama, malın teslim veya arızanın bildirim tarihi gibi bilgiler sayesinde malın ilgili servis istasyonuna bırakılıp onarımın gerçekleşmesi için arıza bildiriminin yapılması gibi önemli işlemler açığa kavuşmaktadır. Bu sayede daha sonra ortaya çıkabilecek herhangi bir ihtilafın çözümü için ilgili belge yol gösterici olacaktır.

Satış Sonrası Hizmetler Yönetmeliğinde Değişiklik Yapılmasına Dair Yönetmelik'in ${ }^{41} 5$. maddesiyle, Satış Sonrası Hizmetler Yönetmeliği m. 11'e eklenen beşinci fikraya göre, onarım, malın kullanıldığı yerde yapılmaktaysa, teslim alma belgesinin düzenlenmesine gerek yoktur. Bu düzenleme ile, servislerin doğrudan, malın bulunduğu yer olan tüketicinin evi veya işyerine giderek onarım faaliyetini gerçekleştirmeleri durumunda, teslim alma belgesi düzenleme zorunluluğu kaldırılmış olmaktadır. Esasen, bu tip durumlarda, onarılacak ürün servise teslim edilmemekte, onarım, ürünün bulunduğu yerde gerçekleştirilmektedir. Bu hâlde de, ayrıca bir teslim alma belgesinin varlığına gerek kalmamış olmaktadır.

Onarım için kargo ile servise gönderilen ürünler hakkında, SSHY m.11/1'deki “kargo ile gönderilen arızalı mallar hariç" ifadesiyle, bu tip ürünler için teslim alma belgesi düzenleme zorunluluğu getirilmemiştir. Öğretide, kargo ile servise gönderilen ürünler için teslim alma belgesi düzenleme zorunluluğunun bulunması, hükmün getiriliş amacına aykırı bulunarak eleştirilmektedir ${ }^{42}$. Teslim alma belgesi düzenlenmesini öngören hükmün konuluş amacı, ürünün servise teslim edildiğine ilişkin bir ispat vesikası oluşturulmasını sağlayarak tüketiciyi korumaktır. Kargo ile servise gönderilen ürünün kaybolması durumunda, tüketici, ürünü ne şikâyetle ve nasıl teslim ettiğini ispatlamakta güçlük çekebilir ${ }^{43}$. Ayrıca, teslim alma belgesinde, ürün ile ilgili ayırt edici özellikler de bulunacağından (telefonlarda IMEI numarası, bilgisayarlarda model ve seri numaraları gibi) ürünlerin kaybolması veya karışmasının önüne geçilecektir. Bununla birlikte, teslim alma belgesinde ürünün servise teslim tarihi belgeleneceğinden hem tüketicinin seçimlik haklarını kullanabilmesi için şartları ispatlayabilmesi kolaylaşacak hem de ürünün garanti kapsamında olup olmadığı ve tamirinin ücrete tabi olup olmayacağı belirlenebilecektir ${ }^{44}$. Bu sebeplerle, tüketicinin korunması amacına hizmet edebilmek için hükümde değişikliğe gidilmesi ve kargo ile gönderilen ürünler açısından da teslim alma belgesinin düzenlenmesinin zorunlu olması gerekir ${ }^{45}$.

\section{Kullanım Hatasını Tespit Etme Yükümlülü̈̆̈̈}

Malların kullanılmasıyla ortaya çıkan zararlardan, üretici/ithalatçı/ satıcıyı sorumlu tutabilmek için, öncelikle malın normal kullanım amaç ve şekillerine uygun kullanılması gerekmekte olup, kullanım k1lavuzu mevcut ise, burada belirtilen kullanımla ilgili kurallara da riayet edilmesi gerekir. Malın normal kullanımı dışındaki kullanımlardan doğan zararlardan, üretici/ ithalatçı/ satıcı aleyhine herhangi bir sorumluluk doğmayacaktır. Bu konuda çoğunluk görüşüne göre, kusurlu olan, malı normal kullanım amacı

b) Malı teslim alanın adı, soyadı ve imzası,

c) Tüketicinin mala ilişkin şikayet ve talepleri,

ç) Malın cinsi, markası ve modeli,

d) Garanti kapsamı içindeki malların arızasının on iş günü içerisinde giderilmemesi halinde üretici veya ithalatçının; malın tamiri tamamlanıncaya kadar, tüketiciye benzer özelliklere sahip başka bir malın verileceğine dair bilgi,

e) Malın teslim veya arızanın bildirim tarihi.

31037 sayılı Yönetmelik (12.02.2020).

Uyumaz, s. 163.

Uyumaz, s. 163.

Uyumaz, s. 163-164.

Uyumaz, s. 164. Kargoyla ürünü teslim alan servis, teslim alma belgesini e-mail, sms ya da belgenin açıkça anlaşılır olduğu başka bir elektronik iletişim vasıtasıyla müşterisine gönderebilir. 
dışında kullanan kişidir ve kanun kusurlu olanları koruma kapsamına almaz ${ }^{46}$. Sorumluluğun tayinini etkileyecek kadar önemli olan bu hususun kimin tarafından tespit edileceğine ilişkin düzenleme GBY m. 11 'dir. Bu düzenlemeye göre, arızalarda kullanım hatasının bulunup bulunmadığını tespit etme, bu konuda rapor düzenleme yetkisi yetkili servis istasyonlarına verilmiştir. Yetkili servis istasyonu mevcut değilse sırasıyla; malın satıcısı, ithalatçısı veya üreticisinden birisi tarafından mala ilişkin azami tamir süresi içinde, kullanım hatası olup olmadığ raporla tespit edilmeli ve bu raporun bir nüshasının da tüketiciye verilmesi zorunludur (GBY m. 11). Bu şekilde bir düzenleme, sorumlu olabilecek kişilerin kendileri hakkında rapor düzenlemelerine imkân tanıdığından ve bu da raporun doğruluğuna gölge düşürebileceğinden, durum tüketici aleyhine görünmektedir ${ }^{47}$. Fakat bu sakıncayı giderip taraflar arasında bir denge kurabilmek adına, aynı maddenin son fikrasında, tüketicinin, söz konusu raporla ilgili, bilirkişi tarafından tespit yapılabilmesi amacıyla, uyuşmazlığın parasal değerine göre, tüketici hakem heyetine veya tüketici mahkemesine başvurabileceği düzenlenmektedir (GBY m. 11/3).

\section{Yedek Parça Stoku Bulundurma Yükümlülüğ̈̈}

Yedek parça stoku bulundurma yükümlülüğü, servis istasyonlarının onarım ve bakım yükümlülükleriyle doğrudan ilişkili bir yükümlülüktür ${ }^{48}$. Bu yükümlülük sayesinde, tüketicinin bakımonarım talebinin karşılanması zamanında ve daha etkin olacaktır ${ }^{49}$. Yedek parça stoku bulundurmayla ilgili 4077 sayılı Kanun döneminde çıkarılan Sanayi Mallarının Satış Sonrası Hizmetleri Hakkında Yönetmelik ile 6502 sayılı Kanuna dayanılarak çıkarılan Satış Sonrası Hizmetler Yönetmeliği farklılık içermektedir. Mülga Kanuna dayanılan Yönetmeliğin 12. maddesinde "Tek servis ile hizmet verilebilecek mallara ait yedek parça stoku, imalatçı-üretici ve/ veya ithalatçının merkezinde veya servis istasyonunda tam olarak bulundurulmak zorundadırlar. Birden fazla yetkili servis istasyonu ile hizmet verilmesi zorunlu olan ürünleri imal veya ithal eden imalatçı- üretici ve/veya ithalatçılar; söz konusu ürünlere ait yedek parçanın tamamını firma merkezlerinde veya belirleyecekleri bir serviste, diğer servis istasyonlarında ise Bakanlıķ̧a belirlenen miktarda yedek parça stoku bulundurmak zorundadırlar" (SMSHY m. 12). Yürürlükte olan SSHY'nin yedek parçayla ilgili düzenlemesi daha kısa olup bu parçaların nerede bulundurulmak zorunda olduğuna değinilmemiştir. Söz konusu madde olan SSHY m. 12'ye göre; üretici veya ithalatçılar, tüketicilerin talebi üzerine yedek parça satışından kaçınamayacaktır. Aynı maddenin ikinci fikrasında ise, servis istasyonlarının, yedek parça fiyat listesini, tüketicilerin görebileceği bir yere asmaları veya katalog hâlinde ya da elektronik ortamda göstermeleri gerektiği düzenlenmiştir. Fiyat listesinin gösterilmesi gerekliliği her iki yönetmelikte de ortaktır fakat yedek parçaların nerede bulunması gerektiği yürürlükteki yönetmelikte belirtilmemiştir. Bunun bir eksiklik olup olmadığ 1 düşünülürse, şu anki düzenlemeye bakıldığında, üretici veya ithalatçılara, tüketicilerin talebi olduğu sürece yedek parça satışı yapmak zorunluluğu şeklinde bir emredici düzenleme yapıldığ 1 görülür. Bu açıdan bakıldığında, yedek parçanın nerede bulundurulması gerektiği düzenlenmemiş olsa bile, üretici/ ithalatçılara yüklenen yedek parça satış zorunluluğu, onların bu parçaları tüketicinin talepte bulunabileceği yerlerde bulundurma yükümlülüğünü de dolaylı olarak getirmiş bulunmaktadır. Ancak, günümüz şartlarındaki hızlı tedarik imkânları göz önüne

Atabek, Reşat. "İmalatçının Üçüncü Kişilere Karşı Sorumluluğu”, BATIDER, C. 10, S. 1, Haziran 1979, s. 159-175, s. 162.

47 Göçer, s. 241; Dokutan, s. 98; Üstün, Zübeyde Meltem, Türk ve Avrupa Birliği Tüketici Hukukunda Imalatçının Hukuki Sorumluluğu, http://dspace.deu. edu.tr/xmlui/handle/12345/11566 (Et: 23.03.2018), s. 79; Türkmen, Ahmet. "Tüketici İșlemlerinde Ayıplı Mal ve Hizmetten Doğan Seçimlik Hakların Tabi Olduğu Zamanaşımı ve Bunun Garanti Taahhütleriyle İlişkisi”, Dokuz Eylül Üniversitesi Hukuk Fakültesi Dergisi, C. 16, Özel Say1 2014, s. 3389-3448, 2015, s. 3439.

48 Esasen, yedek parça üretimi, üretici/ ithalatçı firmaların yaptı̆̆ı bir işlemdir. Ürettiği malı piyasaya sürdükten sonra, o malla ilgili parçaları da tüketiciler açısından belli bir süre ulaşabilir tutması gerekir (SSYH m. 14/5). Yedek parça üretme zorunluluğu, üretici/ ithalatçı firmalar açısından bir zorunluluk olsa da, aynı zamanda onlar için önemli bir gelir kaynağı da oluşturmaktadır. Bkz., Uyumaz, s. 171.

Dokutan, s. 98; Özdemir/ Sarı, s. 99. 
alınırsa, üretici/ ithalatçıların, yedek parça stoklarını mutlaka servislerde bulundurması gerekmeyip, firma merkezinde de yedek parça stoku bulundurabilecekleri kabul edilmelidir ${ }^{50}$.

\section{Onarımın Mümkün Olmadığının Tespitiyle İlgili Yükü̈mlülü̆ğ̈̈}

Ayıplı malın tamir edilmesi, diğer seçimlik haklardan farklı olarak, nitelik itibarıyla aynen ifadır ${ }^{51}$. Onarım bakımından yükümlü olanların bu borçlarını yerine getirebilmeleri için, her şeyden önce, ayıplı malın tamirinin tamamen veya kısmen objektif olarak mümkün olması gerekmektedir ${ }^{52}$. GBY m. 9/1-c'ye göre, yetkili servis istasyonu, satıcı, üretici veya ithalatçı tarafından, bir raporla malın tamirinin mümkün olmadığının tespit edilmesi hâlinde; tüketici diğer seçimlik hakları olan, bedel iadesi, ayıp oranında bedel indirimi veya imkân varsa malın ayıpsız misliyle değiştirilmesini satıcıdan talep edebilir. Satıcı, tüketicinin bu talebini reddedemez. Bu talep yerine getirilmezse, satıcı, üretici ve ithalatçının müteselsil sorumluluğu söz konusu olur.

Onarımın mümkün olmadığının tespiti, maldaki arıza ister ayıp sebebiyle isterse herhangi bir sebepten ileri gelsin, seçimlik hakların bir kez kullanılmasıyla tükenmesi gerektiği ilkesine önemli bir istisna teşkil etmektedir ${ }^{53}$. Bu sayede tüketici, söz konusu tespit üzerine, onarıma alternatif olarak diğer seçimlik haklarına yönelebilecektir ${ }^{54}$.

Ayıplı malın tamir edilmesinin kısmen mümkün olduğu hallerde ise, bu tespit objektif kriterlere göre yapılacak ve sonrasında ayıplı malın objektif olarak tamirinin kısmen de olsa mümkün olduğu anlaşılırsa, tüketicinin talebi üzerine onarım gerçekleştirilecektir. Kısmen onarım gerçekleşse bile, tüketicinin malın ayıplı olmasından kaynaklanan mağduriyeti giderilemeyebileceğinden, ayıptan doğan sorumluluğa bağlı diğer seçimlik hakların da tüketici tarafından kullanılabilmesi mümkün olmalıdır ${ }^{55}$.

\section{YETKİLİ SERVIS SÖZLEŞMESINİN HUKUKİ NITTELİ̆̇̇}

\section{Genel Olarak}

Üretici veya ithalatçılar, satış sonrası hizmet sunmakla yükümlüdür ve bu yükümlülüklerini yerine getirebilmek için de yönetmelikte belirlenen mallarla ilgili, Bakanlık onaylı satış sonrası hizmetler yeterlilik belgesi almak zorundadırlar (TKHK $\mathrm{m}$. 58/1 ve 2). Bu belgeyi aldıktan sonra ise, söz konusu satış sonrası hizmeti, üretici veya ithalatçıların kendileri yerine getirebileceği gibi (iç servis), bu hizmeti sunmaları için başka servislerle de anlaşabilirler (bağımlı servis istasyonu ${ }^{56}$. Bu hâlde, üretici veya ithalatçının satış sonrası hizmeti verirken servis istasyonlarıyla anlaşarak tüketicilere hizmet sunması, yetkili servisler aracılığıyla hareket etmesi, yetkili servis sözleşmesini gündeme getirir. Yetkili servis sözleşmesinin tanımı

Uyumaz, s. 172, dn. 424.

Atamer, Yeşim M./ Baş, Ece. "Avrupa Birliği Hukuku ile Karşılaştırmalı Olarak 6502 Sayılı Yeni Tüketicinin Korunması Hakkında Kanun Uyarınca Satım Sözleşmesinde Ayıptan Doğan Sorumluluk”, İstanbul Barosu Dergisi, C. 88, Özel Sayı, 2014, s. 19-61, s. 35. Seçimlik hakların niteliği ile ilgili bkz., Yavuz, Cevdet/ Acar, Faruk/ Özen, Burak. Türk Borçlar Hukuku Özel Hükümler, Beta Yayınevi, İstanbul 2014, s. 148 vd.

Arbek, s. 176.

Esasen, öğretideki bir görüşe göre, tüketicinin onarım seçimlik hakkını kullanması, aynen ifaya yönelik bir hak olarak nitelendirilmekte ve seçimlik hak olarak kabul edilmemektedir. Bkz., Atamer/ Baş, s. 35; aksi yönde bir görüş için bkz., Yavuz/ Acar/ Özen, Özel, s. 154. Ancak, Yargıtay’ın görüşü, onarım hakkının seçimlik bir hak olduğu yönündedir. Bkz., 13. HD., 14.5.2019, E. 2016/ 30596 K. 2019/ 6097 (Lexpera Hukuk Bilgi Sistemi). Onarım hakkı seçimlik hak olarak kabul edilmezse, onarımın mümkün olmadığg tespit edildikten sonra, tüketicinin diğer haklarına başvurabilmesinin teknik olarak açıklanması daha uygun olmaktadir.

Dokutan, s. 99

Arbek, s. 178. Örneğin, tüketici, kısmen ayıplı olan malın onarımını talep ettikten ve mal onarıldıktan sonra, malın değer kaybı söz konusuysa bedelden indirim hakkını da kullanabilecektir.

Aydoğdu, s. 78 . 
ne kanunda ne de yönetmelikte bulunmaktadır ${ }^{57}$. Bu hâliyle yetkili servis sözleşmesi, bir isimsiz sözleşmedir. İsimsiz sözleşmeler, unsurları itibarıyla tamamen veya kısmen kanunda düzenlenmemiş ya da kanunun başka sözleşme tipleri için düzenlediği unsurların kanunun öngörmediği tarzda bir araya getirilmesiyle oluşan, dolayısıyla kanunda ayrıca düzenlenmeyen veya kanunda ismen bahsedilse bile (mesela ön sözleşme, şerh sözleşmesi vb.) esaslı unsurları gösterilmeyen sözleşmelerdir ${ }^{58}$. İsimsiz sözleşmeler, bileşik sözleşme, karma sözleşme ve kendine özgü yapısı olan sözleşme olmak üzere üçe ayrılır. Bu ayrımlar, isimsiz sözleşmenin nasıl oluşturulduğu, esaslı unsurlarının neler olduğu ve kanunda düzenlenen sözleşmelerle ilişkisi olup olmadığı ve ilişkisi var ise nasıl olduğuna bakılarak sınıflandırmaya tabi tutulmaktadır. Bu nedenle, yetkili servis sözleşmesinin hukukî niteliğini belirlerken, onun kanunda düzenlenmiş diğer sözleşmelerle olan benzerlikleri ve farklılıklarından hareket edilerek bir sonuca gidilmeye çalışlacaktır.

\section{Hukukî Niteliği}

\section{Hizmet Sözleșmesi Açısından}

Hizmet sözleşmesi, TBK'nın 393. maddesinde düzenlenen, işçinin işverene bağımlı olarak belirli veya belirsiz süreyle iş görmeyi ve işverenin de ona zamana veya yapılan işe göre ücret ödemeyi üstlendiği sözleşmedir. İşçinin işverene karşı yerine getirdiği bu hizmet, kısmi süreli olarak fakat düzenli şekilde de görülebilir. Hizmet sözleşmesini oluşturan temel unsurlar; işçinin belirli veya belirsiz bir süre işverene bağımlı olarak bir hizmet görmesi veya görmeyi vaat etmesi, bu hizmetin görülmesinin bir ivaz (ücret) karşı1lığında olması ve tarafların anlaşması ya da anlaşma mevcut olmamasına rağmen bir karşılık ödenmesini gerektirecek hizmet ilişkisinin varlığıdır ${ }^{59}$. Bir özel hukuk sözleşmesi olan hizmet sözleşmeleri, şekle bağlı olmadan yapılabilir. Hizmet sözleşmesi, tam iki tarafa borç yükleyen bir sözleşme olup işçinin kişiliğine bağlıdır.

$57 \quad$ Uygulamada da bu isimle kullanılan yetkili servis sözleşmesiyle ilgili örnek kararlar için bkz.; 19. HD. 18.9.2019, E. 2019/2802 K. 2019/4398; 11. HD. 12.6.2013, E. 2012/13637 K. 2013/12248 (Lexpera Hukuk Bilgi Sistemi); 11. HD. 25.12.2017, E. 2016/5185 K. 2017/7563 (Kazancı İçtihat); 11. HD. 26.12.2017, E. 2016/5208 K. 2017/7595.

58 Yavuz, Cevdet/ Acar, Faruk/ Özen, Burak. Borçlar Hukuku Dersleri Özel Hükümler, Beta Yayınevi, 13. Bask1, İstanbul 2014, s. 13; Feyzioğlu, Necmeddin F. Borçlar Hukuku Hususî Kısım Akdin Muhtelif Nevîleri, C. 1, İstanbul Üniversitesi Hukuk Fakültesi Yayınları, İstanbul 1970, s. 33; Tekinay/ Akman/ Burcuoğlu/ Altop, s. 56; Kuntalp, Erden. Karışık Muhtevalı Akit, 2. Baskı, Bankacılık Enstitüsü Yayınları, Ankara 2013, s. 3; Feyzioğlu, Necmeddin F. Borçlar Hukuku Genel Hükümler, C. 1, İstanbul Üniversitesi Hukuk Fakültesi Yayınları, İstanbul 1976, s. 371; Eren, Fikret. Borçlar Hukuku Özel Hükümler, Yetkin Yayınevi, 6. Bask1, Ankara 2018, s. 865; Eren, Fikret. “İsimsiz Sözleşmelere İlişkin Bazı Sorunlar”, Turgut Akıntürk'e Armă̆an, Beta Yayınevi, 2008, s. 85-111, s. 86; Oğuzman, M. Kemal/ Öz, Turgut. Borçlar Hukuku Genel Hükümler, C. 1, Vedat Kitapçılık, İstanbul 2018, s. 41; Aral, Fahrettin/ Ayrancı, Hasan. Borçlar Hukuku (Özel Borç Iliş̧kileri), 11. Baskı, Yetkin Yayınevi, Ankara 2018, s. 53; Serozan, Rona/ Baysal, Başak/ Sanlı, Kerem Cem. Borçlar Hukuku Özel Bölüm, 4. Baskı, Oniki Levha Yayıncılık, İstanbul 2019, s. 70; Kılıçoğlu, Özel, s.18; Zevkliler, Aydın/ Gökyayla, Emre. Borçlar Hukuku Özel Borç Illişkileri, 18. Baskı, Turhan Kitabevi, Ankara 2018, s. 10; Oktay, Saibe. "İsimsiz Sözleşmelerin Geçerliliği, Yorumu ve Boşlukların Tamamlanması", IÜHFM., C. 55, S. 1-2, 1996, s. 263-296, s. 264; Kuntalp, Erden. Karışık Muhtevalı Akit, Ankara Üniversitesi Hukuk Fakültesi Yayınları, Ankara 1971, s. 9; Hatemi, Hüseyin/ Serozan, Rona/ Arpacı, Abdülkadir. Borçlar Hukuku Özel Bölüm, Filiz Kitabevi, İstanbul 1992, s. 35; Aydoğdu, Murat/ Kahveci, Nalan. Türk Borçlar Hukuku Özel Borç İlişkileri, 4. Baskı, Adalet Yayınevi, Ankara 2019, s. 22; Aktürk Yücer, İpek. İsimsiz Sözleşme Genel Teorisi ve Uzaktan Öğretim Sözleşmesi, Yetkin Yayınları, Ankara 2016, s. 29. İsimsiz sözleşme kavramı ilk kez 12. yüzyılda Roma döneminde Justinianus hukukunda görülmüş ve anlam itibarıyla kullanılmaya başlanmıştır. Bkz., Oktay, s. 266.

59 Yavuz/ Acar/ Özen, s. 475; Eren, Özel, s. 534; Zevkliler/ Gökyayla, s. 452; Yavuz/ Acar/ Özen, Özel, s. 873 vd.; Hatemi/ Serozan/ Arpacı, s. 305 vd.; Kılıçoğlu, Ahmet M. Borçlar Hukuku Özel Hükümler, Turhan Kitabevi, Ankara 2019, s. 387 vd. 
Yetkili servis sözleşmeleri de hizmet sözleşmesi gibi bir iş görme sözleşmesidir. Yetkili servisin göreceği iş, bir malın bakımı, onarımı, montajını, sözleşmede öngörülen şekilde yapmaktır ${ }^{60}$. Her iki sözleşme de belli bir süreçte gerçekleştiği için sürekli sözleşmelerdendir ${ }^{61}$. Üretici veya ithalatçının, satış sonrasında müşterilere hizmet sunmak zorunda olmaları, yetkili servis sözleşmelerinin sürekliliğini gerekli kılar. Hizmet sözleşmesiyle yetkili servis sözleşmesini kıyaslarken dikkate alınacak bir diğer husus, hizmeti gören ile işveren arasındaki bağımlılık ilişkisi noktasıdır. Hizmet sözleşmelerinde yukarıda da belirtildiği gibi, işçi, hizmet borcunu ifa ederken işverene bağımlı olup onun talimatlarıyla hareket etmektedir ve bu durum hizmet sözleşmesini, diğer iş görme borcu doğuran sözleşmelerden ayıran önemli bir özelliktir ${ }^{62}$. Bu hususta, yetkili servis sözleşmesi ile hizmet sözleşmesi arasındaki fark belirginleşmektedir. Yetkili servis sözleşmesinin tarafı olup iş görme borcunu ifa edecek olan servis istasyonları, alanında uzman elemanlardan oluşup teknik bilgiye sahip olan yerleri ifade etmektedir. Yargitay da kararlarında ${ }^{63}$ “ ...Bu istasyonlar satılan araçların teknik özellikleri itibariyle arıza ve ayıbı doğru ve tam teşhis edebilecek, en kısa sürede ve tam anlamıyla giderebilecek elemanlar bulundurmak zorundadır" ş̧eklinde bir ifadeyle servis istasyonlarında uzman, teknik bilgiye sahip eleman bulundurulması gerekliliğini belirtmiştir. Bu teknik bilgiye sahip olmanın, üretici veya ithalatçı karşısında, servis istasyonlarına talimat verme konusunda bir kısıtlama yarattığı ifade edilebilir. Üretici veya ithalatçılar, servis istasyonlarına ancak aralarındaki yetkili servis sözleşmesine uygun davranmaları gerektiği konusunda bir uyarı ve talimatta bulunabilir ve bu talimatın sınırı da yetkili servisin, iş görme borcunu yerine getirebilmesi için kullanması gereken teknik bilgisini kullanmasına engel olunmamasıdır ${ }^{64}$.

Hizmet sözleşmesinin esaslı unsurlarından biri olan ücret konusunda bir karşılaş̧ırma yapılacak olursa durum, garanti süresi içinde ve dışında olmak üzere ikiye ayrılarak incelenmelidir. Garanti kapsamında olan ürünlerde garanti süresi ${ }^{65}$ dolmamışsa, ürünle ilgili arızalarda, garanti veren ücretsiz onarım hizmeti sunmak durumundadır ${ }^{66}$. Bu sebeple servis istasyonları da yaptıkları bakım-onarım hizmeti karşılığında tüketiciden herhangi bir ücret talep edemeyeceklerdir. Ancak servis istasyonları, işçilik masrafının karşılığ 1 olarak, yetkili servis sözleşmesi kapsamında üretici veya ithalatçıdan ücret talebinde bulunabilecektir. Bu şekilde bir ücret ödemesinin varlığ yetkili servis sözleşmesini hizmet sözleşmesine yaklaştırsa da, salt bir hizmetin karşıllı̆ında ücret ödeme borcunun olması, hizmet sözleşmesi nitelendirmesi için yeterli olmayacaktır. Garanti kapsamı dışındaki ürünlerde, tüketici elindeki ürünü haricen tamir ettireceğinden yetkili servis istasyonuna bir ücret ödeme borcu doğar. Burada üretici/ ithalatçının herhangi bir sorumluluğu söz konusu olmayıp, tüketici ve yetkili servis istasyonu arasındaki ilişki ön planda olduğundan, üretici/ ithalatçı ile servis istasyonu arasında hizmet ilişkisinin varlığından söz edilemez ${ }^{67}$.

\section{Eser Sözleşmesi Açısından}

Eser sözleşmesi, yüklenicinin bir eser meydana getirip işsahibine teslim etmeyi üstlendiği, işsahibinin de bunun karşılı̆̆ında bir bedel ödemeyi üstlendiği sözleşmedir ${ }^{68}$ (TBK m. 470). Bu

\footnotetext{
$60 \quad$ Dokutan, s. 103.

61 Yetkili servis sözleşmesinin sürekli edimli bir sözleşme olduğu yönünde bkz., Uyumaz, s. 28.

62 Yavuz/ Acar/ Özen, s. 475; Kılıçoğlu, Özel, s. 387; Hatemi/ Serozan/ Arpac1, s. 305; Eren, Özel, s. 535.

63 HGK. 5.10.2005, E. 2005/487 K. 2005/553 (Lexpera Hukuk Bilgi Sistemi); HGK. 25.02.2004, E. 2004/484 K. 2004/99, (Sinerji İçtihat Programı).

64 Dokutan, s. 104.

65 Garanti Belgesi Yönetmeliği m. 6/1'ye göre; “Garanti süresi; malın tüketiciye teslim tarihinden itibaren başlar ve asgari iki yıl veya bu Yönetmeliğe ekli listedeki ölçü birimi ile tespit edilen değer kadardır." Göçer, s. 109.

Göçer, s. 71; Dokutan, s. 105.

Eren, Özel, s. 583; Yavuz/ Acar/ Özen, s. 537; Zevkliler/ Gökyayla, s. 489; Säcker, Franz Jürgen/ Rixecker, Roland/ Oetker, Hartmut/ Limperg, Bettina. Münchener Kommentar zum BGB, 8. Auflage, Verlag C.H.
} 
sözleşmenin esaslı unsurları, bir eseri meydana getirme, bedel ödeme ve anlaşmadır. Eser meydana getirme karşılığında bedel ödenmesi öngörülmezse ya bir vekâlet sözleşmesi ya da isimsiz bir işgörme sözleşmesinin varlığından bahsedilebilir ${ }^{69}$. "Meydana getirme" kavramından anlaşılması gereken ise sadece var olmayan, yeni bir şey ortaya koymayı değil, kavramı geniş yorumlayarak var olan bir şeyi değiştirme, onarma ve hatta yok etme de bu kapsamda değerlendirilmelidir ${ }^{70}$. Bir malın onarımı da eser sözleşmesinin konusu kapsamında olabileceğinden, yetkili servis sözleşmesiyle eser sözleşmesi, aralarında benzerlik gösterir ${ }^{71}$.

Eser sözleşmeleri, bir eser meydana getirmeye yönelik olduğundan edimin ifası belli bir zaman alır. Bu durum, edimin sürekli borç ilişkisi doğuran bir ifa türü olduğu izlenimini uyandırsa da sözleşmenin yapılmasıly eserin tamamlanması arasında ne kadar uzun süre olursa olsun, yine de ani edimli bir sözleşmedir ve ifa tek seferde yerine getirilmekle tamamlanır ${ }^{72}$. Yetkili servis sözleşmesi ise, üretici/ ithalatçı ve servis istasyonları arasında belli bir zaman sürecek olan ilişkiyi kapsadığından ve bu süre içerisinde servis istasyonlarının bakım-onarım yükümlülüklerinin bulunmasından dolayı sürekli nitelikte bir sözleşme olup bu yönüyle eser sözleşmesinden ayrılmaktadır ${ }^{73}$.

Yetkili servis sözleşmesini eser sözleşmesiyle karşılaştırırken incelenmesi gereken bir diğer husus, ücret konusudur. Bir eser meydana getirme karşılığında ödenmesi gereken ücret, eser sözleşmesinin asli unsurlarından biridir ${ }^{74}$. Yetkili servis sözleşmelerinde ücret ödenmesi gereken durumlar incelenirken ikili bir ayrım yapılmalı ve bakım-onarımın garanti süresi içinde mi dışında mı olduğuna bakılmalıdır. Garanti süresi içinde, servis istasyonlarının yaptıkları bakım ve onarımların masrafları tüketiciden karşılanamayacak olup, üretici/ ithalatçıdan, yetkili servis sözleşmesi uyarınca talep edilebilecektir. Bu hâlde, onarımın ücret karşılığı yapılmış olması yetkili servis sözleşmesini eser sözleşmesine yaklaştırmaktadır. Fakat sözleşme konusu olan bakım-onarımın eser sözleşmesindeki gibi ani edimli sözleşme olmayıp sürekli nitelik taşıyan bir sözleşme olması farkı ortaya koymaktadır. Garanti süresi kapsamı dışında kalan bakım-onarımlarda ise, tüketici doğrudan servis istasyonlarına müracaat edip onlarla sözleşmesel bir ilişkiye girdiğinden, masrafların karşılanması borcu da tüketiciye ait olacaktır ve üretici/ ithalatçının bu konuda bir borcu olmayacaktır.

Tüketici ve yetkili servis istasyonları arasındaki ilişki, servis istasyonuna garanti belgesi kapsamında başvurulmamışsa, eser sözleşmesidir ${ }^{75}$. Yargıtay da bir kararında ${ }^{76}$ : "Taraflar arasındaki uyuşmazlık istisna (eser) sözleşmesinden kaynaklanmakta olup davada, davacının aracına servis hizmeti veren davalının ayıpl yedek parça ve hizmeti nedeniyle oluşan zararın tahsili istenmiş..." şeklinde belirleme yapmış ve diğer kararlarında da servis istasyonlarına getirilen ürünlerin tamiriyle ilgili işlemlerin, eser sözleşmesi

Beck, München 2020, BGB § 631, Rn. 1; Gümüş, Mustafa Alper. Borçlar Hukuku Özel Hükümler, C. 2 , 3. Baskı, Vedat Yayıncılık, İstanbul 2014, s. 1; Selimoğlu, Yaşar Engin. Eser Sözleşmesi, 4. Baskı, Adalet Yayınevi, Ankara 2017, s. 15.

Eren, Özel, s. 595; Yavuz/ Acar/ Özen, Özel, s. 994; Kılıçoğlu, Özel, s. 450.

Eren, Özel, s. 594; Yavuz/ Acar/ Özen, s. 539; Hatemi/ Serozan/Arpacı, s. 348; Zevkliler/ Gökyayla, s. 495. Dokutan, s. 106; Kılıçoğlu, Özel, s. 446.

Säcker/ Roland/ Oetker/ Limperg, BGB § 631, Rn. 1. Bu konuda doktrinde ve uygulamada savunulan görüşler için bkz.; Gümüş, s. 2.

Dokutan, s. 106.

Tandoğan, Haluk. Borçlar Hukuku Özel Borç İlişkileri, C. 2, 5. Tıpkıbasım, Vedat Yayıncılık, İstanbul 2010, (Borçlar), s. 24; Säcker/ Roland/ Oetker/ Limperg, BGB § 632, Rn. 3; Kılıçoğlu, Özel, s. 446; Aral/ Ayranc1, s. 366.

75 Burada, servis istasyonu, onarım faaliyeti için tüketiciden ücret talep edebilmektedir. Bkz., Göçer, s. 237.

76 15. HD. 25.01.2005, E. 2004/3516 K. 2005/230 (Kazancı İçtihat Programı). Aynı yöndeki kararlar için bkz., 20. HD. 10.9.2018, E. 2018/3868 K. 2018/5467; 3. HD. 2.11.2015, E. 2014/21196 K. 2015/17002 (Lexpera Hukuk Bilgi Sistemi). 
kapsamında olduğunu kabul etmiştir ${ }^{77}$. Garanti süresi dışında yapılan onarımlarda, üretici/ ithalatçı ve servis istasyonu arasında yapılan işin karşılığı olarak bir ücret ödenmesi söz konusu olmadığından, bir eser sözleşmesinin varlığından da bahsedilemeyecektir ${ }^{78}$.

\section{Vekâlet Sözleşmesi Açısından}

Türk Borçlar Kanunu'nun 502. maddesine göre; "Vekâlet sözleşmesi, vekilin Vekâlet verenin bir işini görmeyi veya işlemini yapmayı üstlendiği sözleşmedir". Vekil, vekâlet verene karşı belirli bir işi görmeyi borçlanırken bunu vekâlet verenin menfaat ve iradesine uygun olarak yapmak zorundadır ${ }^{79}$. Kanundaki tanımın vekâlet sözleşmesinin unsurlarını ve kapsamını tam olarak ifade etmemesinden dolayı, doktrindeki vekâlet sözleşmesi ile ilgili farklı tanımlar yapılmıştır. Bir tanıma göre, "Vekâlet sözleşmesi öyle bir sözleşmedir ki, vekil, vekâlet veren ile arasindaki özel güven ilişkisine dayalı şekilde, vekâlet verenin menfaat ve hesabına olarak ve nispeten yersel, zamansal veya maddi bağımsızlık içerisinde bir iş veya hizmeti, ücretsiz veya sözleşmede kararlaştırılmış ya da teamül varsa ücretli olarak görmeyi borçlanır" ${ }^{\prime \prime 0}$. Bir diğer tanımda ise; "Vekâlet sözleşmesi, vekilin sözleşme ile belirlenen işi görmeyi veya işlemi yapmayı borçlandiğı ve vekilin yerine getireceği edimin kanun hükümleriyle düzenlenen akitlerden herhangi birinin konusuna girmediği, buna karşıllı ancak sözleşme veya teamül olan durumlarda vekilin ücrete hak

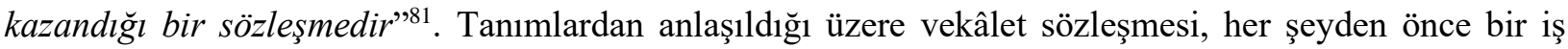
görme sözleşmesidir. Vekâlet sözleşmesi için, kanunda belirtildiği gibi, niteliklerine uygun düştüğü ölçüde, kanunda düzenlenmemiş (isimsiz) sözleşmelere de uygulandığından bir tür şemsiye ya da torba işgörme sözleşmesi olarak kabul edilebilir ${ }^{82}$.

Yetkili servis sözleşmesi, konusu itibarıyla bir işgörme sözleşmesidir ve bu açıdan, vekâlet sözleşmesiyle benzerlik göstermektedir. Vekâlet sözleşmesinde ücret zorunlu bir unsur olmadığından, ücret ödenmesi kararlaştırılmadığı müddetçe eksik iki tarafa borç yükleyen bir sözleşmedir. Fakat uygulamada özellikle bankalar ve serbest meslek faaliyetleri yönünden, vekâlet sözleşmelerinde ücret çoğunlukla kararlaştıııldığından sözleşmede bir karşılıklılık (synallagma) ilişkisi meydana gelmekte ve artık ivazlı vekâlet kural, ivazsız vekâlet ise istisna haline gelmiş bulunmaktadır ${ }^{83}$.

Vekâlet sözleşmesinin doğurduğu borç ilişkisinin sürekli mi ani edimli mi olduğu doktrinde tartışmalıdır. Hâkim görüşe göre, her somut olay açısından durum ayrıca değerlendirilmeli ve yüklenilen iş veya hizmetin türüne göre sürekli edimli veya ani edimli bir sözleşme olduğu tespit edilmelidir ${ }^{84}$. Edimin net bir şekilde sürekli veya ani olduğunun belirlemesi yapılamadığında ve edim sürekli olmamakla birlikte uzunca bir süre devam ediyorsa, sürekli sözleşme benzeri bir sözleşme olarak nitelenebilecektir ${ }^{85}$. Burada önemli olan, vekilin yaptığı işin bir kerede mi yoksa zaman içerisinde mi ifa edildiğinin belirlenmesidir ${ }^{86}$. Yetkili servis sözleşmeleri ise süreklilik arz eden sözleşmelerden olduğundan, ani edimli sözleşme olarak

77 15. HD. 20.12.2017, E. 2016/3634 K. 2017/4507 (Kazanc1 İçtihat Program1).

$78 \quad$ Dokutan, s. 107.

79 Eren, Özel, s. 705; Yavuz/Acar/Özen, s. 631; Zevkliler/ Gökyayla, s. 632; Gümüş, s. 121.

80 Gümüş, s. 122; Gümüş, M. Alper. Türk-İsviçre Borçlar Hukukunda Vekilin Özen Borcu, Beta Yayınevi, İstanbul 2001, s. 11-12.

81 Yavuz/ Acar/ Özen, s. 632.

$82 \quad$ Eren, Özel, s. 706.

83 Eren, Özel, s. 707. Yavuz/ Acar/ Özen, s 637; Gümüş, s. 129-130; Zevkliler/ Gökyayla, s. 604; Başpınar, s. 78 vd; Tandoğan, C. 2, s. 365; Başpınar, Veysel. "Avukatlık Sözleşmesi ve Ücreti Hakkında Bazı Düşünceler”, Ankara Barosu Hukuk Kurultayı, C. 3, 2004, s. 463-478, s. 465; Akınc1, Şahin. Vekâlet Sözleşmesinin Sona Ermesi, Sayram Yayınları, Konya 2004, s. 9; Emiroğlu, Haluk. "Roma Hukuku'nda Vekâlet Sözleşmesi (Mandatum) ve Hukuki İşlemlerde Temsil”, Ankara Üniversitesi Hukuk Fakültesi Dergisi, C. 52, S. 1, 2003, s. 101-111, s. 105.

84 Gümüş, s. 123; Gümüş, Özen, s. 22.

85 Eren, Özel, s. 708.

86 Zevkliler/Gökyayla, s. 635. 
kabul edilemez ${ }^{87}$. Ancak tüketici ile yetkili servis sözleşmesi arasındaki ilişkide, ani edimli bir sözleşmenin söz konusu olduğu kabul edilebilir.

Vekâlet sözleşmesinin unsurlarına değinilecek olursa bunlar; bir iş veya hizmetin görülmesi, işgören vekilin bağımsızlığı, işgörmenin başkasının menfaati ve iradesine uygun yapılması, işgörmede zaman kaydına bağlı olunmaması, işgörme sonucunda vekilin başarılı bir sonuç elde edilememesi tehlikesini taşımaması ve tarafların anlaşmasıdır. Ücret ise kural olarak vekâlet sözleşmesinde zorunlu bir unsur olmayıp, ancak sözleşmede kararlaştırılmışsa veya teamül varsa gündeme gelecektir ${ }^{88}$. Yetkili servis sözleşmesinde ücret, garanti kapsamında kalan ürünlerin bakım-onarımlarında, üretici/ ithalatçı tarafindan karşılandı ̆̆ı için sözleşmenin temel unsurlarından biri denilebilir. Diğer unsurlar açısından bir değerlendirme yapmak gerekirse, işgörmenin ve vekilin bağımsızlığı hususlarının hem vekâlet hem yetkili servis sözleşmesinde benzeşmekte olduğu görülür. Fakat vekâlet sözleşmesindeki bağımsızlık daha nisbi bir görünüm arz etmekte olup, vekâlet verenin talimat ve iradesine uygun hareket etme yükümlülügü bulunmaktadır. Yetkili servis sözleşmesinde, servis istasyonu görevi gereği uzmanlık gerektiren teknik bilgiye sahip olduğundan nisbi bağımsızlığı daha geniş kabul edilecektir. Ancak, üretici/ ithalatçının servise gelen işleri denetleme ve servisin hizmeti yerine getirmesi ile ilgili talimat verme yetkisi devam edecektir.

Yetkili servis sözleşmesi ile vekâlet sözleşmesini birbirine yaklaştıran bir diğer husus, vekâlet sözleşmesinin bazı türlerinde kendini gösteren zaman kaydına bağlı olmama veya süreklilik hususudur. Bilindiği üzere, yetkili servis istasyonlarının üretici/ ithalatçıyla anlaşmaları genelde uzun bir zaman dilimini kapsar ve süreklilik arz eder.

Öğretideki bir görüşe göre, vekâlet sözleşmesiyle sağlanan önemli imkânlardan biri olan her zaman fesih hakkı (TBK.m.512), yetkili servis sözleşmesine uygulanamayacağından, bu sözleşme vekâlet sözleşmesi olarak kabul edilemez ${ }^{89}$. Türk ve İsviçre doktrininde hâkim görüşe göre, güven ilişkisinin sonucunda, haklı bir sebep göstermek zorunda kalmaksızın sözleşme taraflarınca kullanılabilen "her zaman fesih hakk»", vekâlet sözleşmesinin emredici nitelikte bir unsudur ${ }^{90}$. Bu hakkın tanınmasının sebebi, vekâlet veren ile vekilin arasındaki yoğun güven ilişkisidir. Yetkili servis sözleşmesinde ise, tipik vekâlet sözleşmeleri olan avukatlık, hekimlik, mimarlık sözleşmelerinde olduğu gibi kişisel ve yoğun bir güven ilişkisi bulunmamaktadır. Ancak, bu durum, her zaman fesih hakkının yetkili servis sözleşmesine uygulanamayacağına veya bu sözleşmenin vekâlet sözleşmesine yakın bir sözleşme olmasına engel değildir. Zira, yetkili servis sözleşmesi, isimsiz bir işgörme sözleşmesidir. Böylece, TBK m.502/2 atfi gereğince, vekâlet sözleşmesine ilişkin hükümler, yetkili servis sözleşmesinin niteliğine uygun düştüğü ölçüde, bu sözleşmeye de uygulanacaktır ${ }^{91}$. Dolayısıyla, yetkili servis sözleşmeleri için de TBK m.512'de düzenlenen her zaman fesih hakkı mümkün olacak ancak, tipik vekâlet sözleşmelerinden farklı olarak, bu düzenlemenin aksi, üretici/ ithalatçı ve yetkili servis arasındaki sözleşmede kararlaştırılabilecektir ${ }^{92}$.

\section{Tam Üçüncü Kişi Yararına Sözleşme Açısından}

Bir sözleşmede taraflar, edimlerden biri veya bazılarının, alacaklı yerine, sözleşmeye taraf olmayan bir üçüncü kişiye ödenmesini kararlaştırmışlarsa, bu hâlde üçüncü kişi yararına sözleşmeden bahsedilir

\footnotetext{
$87 \quad$ Dokutan, s. 108.

88 Yavuz/ Acar/ Özen, s. 637 vd.; Gümüş, s. 124 vd.; Zevkliler/ Gökyayla, s. 638 vd.; Eren, Özel, s. 708 vd. Alman hukukunda vekâletin ücretli yapılamayacağına ilişkin olarak bkz., Säcker/ Roland/ Oetker/ Limperg, BGB $\S 662$, Rn. 1-3.

$89 \quad$ Dokutan, s. 108.

90 Gümüş, s. 129; Kılıçoğlu, Özel, s. 548.

91 Uyumaz, s. 26.

92 Uyumaz, s. 366
} 
(TBK m. 129) ${ }^{93}$. Üçüncü kişi yararına sözleşme, sözleşmelerin sadece taraflar arasında hüküm ve sonuç doğurmasını ifade eden nisbilik ilkesinin istisnalarından birini teşkil eder. Çünkü bu sözleşmeyle üçüncü kişinin hukuk alanına bir etkide bulunulmaktadır ${ }^{94}$. Her ne kadar üçüncü kişinin hukuk alanı, sözleşmeyi yapan taraflarca bir etkiye maruz kalsa da bu durum üçüncü kişiyi o sözleşmenin bir tarafı haline getirmez, üçüncü kişi yararına sözleşmenin önemli olan yanı da budur. Üçüncü kişi yararına sözleşmeyi yapanlar; üçüncü kişi lehine hüküm koydurtan vaat ettiren ve ifayı üçüncü kişiye yapmayı üstlenen vaat edendir. Kendisi yararına işlem yapılan üçüncü kişi ise lehtardır (yararına işlem yapılan). Bu üçlü ilişki temsile benzemekle birlikte, vaat ettirenin sözleşmeyi kendi adına yaptırması sebebiyle üçüncü kişinin temsilcisi olmadığı söylenebilir. Üçüncü kişi de ifayı kendi adına elde edip vaat ettirenin temsilcisi konumunda olmadığından temsil ilişkisinin söz konusu olmadığı ifade edilebilir ${ }^{95}$.

TBK m. 129'da tanımlanan üçüncü kişi yararına sözleşmenin, temel olarak eksik üçüncü kişi yararına sözleşmeye ait olduğu görülmektedir. Tam ve eksik üçüncü kişi yararına sözleşme ayrımı, üçüncü kişinin ifayı talep etme yetkisine sahip olup olmamasına göre yapılır. Eğer üçüncü kişi, sadece ifayı kabul yetkisine sahipse (eski ifadeyle, edayı kabzetme yetkisi) eksik üçüncü kişi yararına sözleşme söz konusudur. Bu hâlde, borcun ifa edilmemesi durumunda, üçüncü kişinin herhangi bir hukukî yola başvurma imkânı olmayıp ancak sözleşmenin tarafı olan vaat ettiren, edimin üçüncü kişiye ifasını vaat edenden talep edebilir. Tam üçüncü kişi yararına sözleşmede ise, üçüncü kişinin, ifanın kendisine yapılması hususunda bir takım hakları vardır ve talepte bulunma yetkisini de haizdir. Bu sebeple tam üçüncü kişi yararına sözleşmelere “üçüncü kişi yararına hak veren sözleşme”" de denilmektedir".

Üçüncü kişi yararına sözleşmeler, TBK'nın özel hükümler bölümünde düzenlenen sözleşme tipleri gibi, bağımsız bir sözleşme türü oluşturmaz. Bu sayede üçüncü kişi yararına sözleşme, kanunda düzenlenmiş olan sözleşmeler veya atipik, bileşik ve karma sözleşmeler gibi isimsiz sözleşmelerle de beraber kullanılabilecektir ${ }^{97}$.

Yetkili servis sözleşmesinde, sözleşmenin tarafları üretici/ ithalatçı ve servis istasyonu olmakla birlikte, servis istasyonundan bakım ve onarım için talepte bulunan tüketicilerdir. Tüketiciler, servis istasyonuyla aralarında bir sözleşme olmadan talepte bulunabildiklerinden, yetkili servis sözleşmesi, üçüncü kişi yararına sözleşmedir. Yetkili servis sözleşmesi, üçüncü kişi olan tüketiciye, satış sonrası

Eren, Genel, s. 1141; Huguenin, Claire. Obligationenrecht-Allgemeiner und Besonderer Teil, Schulthess Verlag, Zürich 2012, N. 1119; Bucher, Eugen. Schweizerisches Obligationenrecht, 2., neubearbeitete und erweiterte Auflage, Schultess Verlag, Zürich 1988, s. 473; Becker, H. İsviçre Medenî Kanunu Şerhi VI. Cilt Borçlar Kanunu, IV. Fasikül, Ankara Yarı Açık Cezaevi Matbaası, Ankara 1972 (Çev: Saim Özkök), s. 49; Hatemi/ Gökyayla, s. 293; von Tuhr, Andreas. Borçlar Hukukunun Umumi Kısmı, C. 1-2, Yargıtay Yayınları, Ankara 1983 (Çev: Cevat Edege), s. 715; Oğuzman, M. Kemal/ Öz, M. Turgut. Borçlar Hukuku Genel Hükümler, C. 2, 12. Bask1, Vedat Kitapçılık, İstanbul 2016, s 437; Akınc1, s. 260; Kılıçoğlu, s. 745; Krüger/ Gottwald. Münchener Kommentar zum BGB, Band 3, 8. Auflage, Verlag C.H. Beck, München 2019, BGB § 328 Rn. 1

94 Hatemi/ Gökyayla, s. 294; Oğuzman/ Öz, C. 2, s. 440; Eren, Genel, s. 1141. Üçüncü kişi yararına sözleşmenin niteliği ile ilgili teoriler için bkz., Becker, s. 49.

95 Huguenin, N. 1129; Eren, Genel, s. 1142; Oğuzman/ Öz, s. 437; Hatemi/ Gökyayla, s. 293; von Tuhr, s. 718. 96 von Tuhr, s. 716 vd.; Huguenin, N. 1137; Eren, Genel, s. 1146; Hatemi/ Gökyayla, s. 294; Oğuzman/ Öz, s. 439 vd.: Akıncı, s. 262. Ayrıca üçüncü kişi yararına sözleşmeyi tam ve eksik olarak ayırmanın yanı sıra, doktrinde kimi zaman isimlendirme farklı yapılarak "gerçek" ve "gerçek olmayan üçüncü kişi yararına sözleşme" şeklinde de ifade edilebilmektedir. Bkz., Huguenin, N. 1133, 1137; Hatemi/ Gökyayla, s. 294. Üçüncü kişi yararına sözleşmenin eksik mi tam mı olduğunun tespiti, her şeyden önce taraf iradelerine bakılarak belirlenir. Tarafların iradesinin tespiti için yorum yoluna da başvurulabilir. Eğer taraf iradeleri, yorum yoluyla da anlaşılamıyorsa veya bu konuda boşluk varsa, örf ve âdete bakılarak bir sonuca varmaya çalışılır. TBK m. 129/2'de bu iki kıstası belirtse de, tam üçüncü kişi yararına sözleşmelerin doğrudan kanuna dayandığ 1 hâllerin (TTK m. 1478, TBK m. 130, TTK m. 1454 vs.) de dikkate alınması gerekmektedir. Bkz., Oğuzman/ Öz, s. 441 vd.: Eren, Genel, s. 1146; Hatemi/ Gökyayla, s. 294; Akınc1, s. 262. 
hizmetler için talep hakkı verdiğinden tam üçüncü kişi yararına (gerçek üçüncü kişi yararına) sözleşme kapsamına girer ${ }^{98}$. Bunun sonucu olarak, tüketici, üretici/ ithalatçının sahip olduğu, servis istasyonundan servis hizmetini yerine getirmesini talep etme hakkına sahip olur. Tüketici, servis istasyonundan hizmet talep etse dahi, yetkili servis sözleşmesinin tarafı hâline gelmez. Vaat ettiren konumunda bulunan üretici/ ithalatçı ise, tüketicinin servis istasyonundan ifa talebinde bulunmasından sonra, bu hak üzerinde tasarruf edemez.

Yetkili servis sözleşmesi, üçüncü kişi yararına bir sözleşme olduğundan ve tüketici, bu sözleşmenin bir tarafı olmadığından, servis istasyonunun ayıplı ifası veya hizmeti sebebiyle tüketicinin, yetkili servis sözleşmesinden dönme imkânı olmayacaktır. Servis istasyonunun ayıplı hizmet sunması nedeniyle doğacak sorumlulukta, SSHY m.14'e göre üretici/ ithalatçı ve servis istasyonları müteselsilen sorumlu olurlar.

\section{TBK m. 66 Açısından İnceleme}

TBK m. 66'da düzenlenen "adam çalıştıranın sorumluluğu”, kusursuz sorumluluk hâllerinden özen sorumluluğu kapsamında bir sorumluluk türü olup, kurtuluş kanıtı getirilebilen bir sorumluluktur. Kanundaki tanımına göre: "Adam çalıştıran, çalışanın, kendisine verilen işin yapılması sırasında başkalarına verdiği zararı gidermekle yükümlüdür" şeklinde düzenlenmiştir (TBK m. 66). Bu sorumluluk türünün düzenlenmesi sayesinde adam çalıştıranlar, çalıştıracakları kişileri seçerken, onlara talimat verirken, işleri gördürürken daha dikkatli ve özenli davranacaklar ve buna bağlı olarak herhangi bir zarar meydana gelme ihtimali azalacaktır. Kusursuz bir sorumluluk türü olarak adam çalıştıranın sorumluluğunun düzenlenmiş olması, esasında adalet ve hakkaniyet düşüncelerine dayanır. $\mathrm{Bu}$ sorumlulukta, adam çalıştıranın kişisel durumu değil objektif olarak bir yükümlülük söz konusudur ${ }^{99}$

Adam çalıştıranın sorumluluğu için gereken şartlar, kusur hariç olmak üzere haksız fiilin genel şartları olan; fiil, hukuka aykırılık, zarar, illiyet bağıdır. Bu sorumluluk türüne özel olarak aranan şartlar ise; çalışanla çalıştıran arasında bir çalıştırma (bağımlılık) ilişkisi bulunması; zararın, çalışanın işi gördüğü sırada hukuka aykırı bir davranışıyla meydana gelmiş olması ve adam çalıştıranın kurtuluş kanıtı getirememiş olmasıdır ${ }^{100}$.

TBK m. 66 bağlamında bir adam çalıştırmanın söz konusu olabilmesi için, çalışan ile çalıştıran arasında bir hizmet sözleşmesinin bulunması zorunlu değildir. Hatta aralarında herhangi bir sözleşmenin varlığına da gerek yoktur. Burada önemli olan, çalışanın, adam çalıştıranın emir ve talimatıyla sıkı sıkıya bağlı olmasıdır ${ }^{101}$. Bu bağımlılığın en önemli unsuru ise, çalışanın hizmetinin, adam çalıştıranın amaç ve menfaatine yönelik olmasıdır ${ }^{102}$. Yetkili servis sözleşmesinin tarafları arasındaki bağımlılık ilişkisini incelerken ikili bir ayrım yapmak gerekir. Üretici/ ithalatçılar, satış sonrası hizmetleri sağlarken kendileri bir servis istasyonu kurabileceği gibi (iç servis), kurulmuş bulunan servis istasyonlarına yetki vermek suretiyle de bu hizmeti sağlayabilir (bağımlı servis istasyonu/ anlaşmalı özel servis) ${ }^{103}$. İç servisler,

\footnotetext{
$98 \quad$ Dokutan, s. 109.

99 von Tuhr, s. 392 vd.; Oğuzman/Öz, s. 140-141; Eren, Genel, s. 618 vd.; Kılıçoğlu, s. 424-425; Hatemi/ Gökyayla, s. 151; Akıncı, s. 157; Tandoğan, Haluk. Türk Mesuliyet Hukuku (Akit Dışı ve Akdi Mesuliyet), Vedat Kitapçılık, Ankara 1961, (Mesuliyet), s. 106 vd.

Kilıçoğlu, s. 425 vd.; Eren, Genel, s. 621 vd.; Tandoğan, Mesuliyet, s. 109 vd.; Oğuzman/ Öz, s. 145 vd.; Akınc1, s. 157; Säcker, Franz Jürgen/ Rixecker, Roland/ Oetker, Hartmut. Münchener Kommentar zum BGB, 7. Auflage, Verlag C.H. Beck, München 2017, Rn. 14 ff.

101 Kilıçoğlu, s. 425; Eren, Genel, s. 622; Tunçomağ, Kenan. Türk Borçlar Hukuku, Genel Hükümler, C. 1, Sermet Matbaası, İstanbul 1968, s. 309. Yargıtay da yeni tarihli bir kararında adam çalıştırma ilişkisi ile ilgili; “... Adam çalıştırma ilişkisi için çalıştırılanın, çalıştıranın buyruğu altında olması, onun gözetiminde işi yapması ve onun talimatıyla bağlı bulunması gerekir..." ifadesini kullanmıştır. HGK 01.11.2017, E. 2017/17-1315 K. 2017/1239 (Kazancı İçtihat Programı). Aydoğdu, s. 194.
} 
doğrudan üretici/ ithalatçıya bağlı olup onun bünyesinde faaliyet göstermesinden dolayı, bağımlılık ilişkisinin varlığı kabul edilerek TBK m. 66 bağlamında bir adam çalıştırmanın söz konusu olduğu ifade edilmelidir.

Bağımlı servis istasyonlarında ise, her ne kadar isminde bağımlı ifadesi geçse de, bu ifade ancak aradaki sözleşmeyi ve yetkilendirmeyi belirtmek için kullanılmış olup, TBK m. 66 bağlamında bir "bağımlılık ilişskisini" göstermez. Bağımlı servis istasyonlarının kendi ad ve hesaplarına çalışmaları, ekonomik, idari ve teknik anlamdaki bağımsızlıklarından ötürü, işverene bağımlı olup "çalışan" statüsüne sahip değildir. Bu konuyla ilgili bir Yargıtay kararında ${ }^{104}$ da: “... Konu ile ilgili olarak tartışılması gereken yön, davalı ile yetkili kildığgl, belge verdiği servis arasındaki ilişkinin belirlenmesidir. Aralarında bir çalışan-çalıştıran ilişkisi olmadı̆̆ açıktır. Diğer bir ifadeyle yetkili servis, BK'nın 55. maddesindeki ilkelere bağlı kalınmak suretiyle onun talimatı ve denetimi altında çalıştı̆̆ı düşünülemez. BK'nın 55. maddesindeki düzenlemede, çalışan, çalıştıranın denetim ve talimatı altında ve ekonomik yararı ve sonuçları çalıştıranın malvarlığında sonuç doğuracak biçimde iş yapan bir kimsedir. Somut olayda yetkili servis ile davalı arasındaki ilişki itibariyle yetkili servisin kendi nam ve hesabına davalıdan bağımsız olarak çalıştığı görülmektedir. Ancak davalı ile yetkili servis arasında bir sözleşmenin bulunduğu tartışmasızdır..." şeklinde belirleme yapılmıştır. Yargıtay da burada bir adam çalıştırma ilişkisi olduğunu kabul etmemiş, bunu da servis istasyonuyla üretici/ ithalatçı arasında bir çalışan-çalıştıran ilişkisinin olmadığına ve buna bağlı olarak da talimat ve denetim altında çalışılmadığına vurgu yaparak gerekçelendirmiştir ${ }^{105}$. Sonuç olarak, yetkili servis sözleşmesinin hizmet sözleşmesinden farklı nitelikte olması, servis istasyonunun üretici/ ithalatçının işletmelerinin organizasyonu kapsamında olmayıp fizikî ve idarî anlamda ayrılık göstermesi, dolayısıyla üretici/ ithalatçının servis istasyonuna emir ve talimat verememesi gibi durumlar, burada TBK m. 66 anlamında bir bağımlılık ilişkisi olmadığını kanıtlamaktadır. Yargıtay'ın kararında belirtildiği üzere, "çalışan” kavramı tanımlanırken, “...çalıştıranın denetim ve talimatı altında..." ifadesi kullanılarak yetkili servisin çalışan olmadığ 1 belirlemesi yapılmıştır. Burada dikkat edilmesi gereken yön, yetkili servislerin ekonomik ve idari bağımsızlıklarından ötürü, üretici/ ithalatçının talimatlarıyla bağlı olmamalarıyla beraber, aralarındaki yetkili servis sözleşmesine dayanarak, üretici/ ithalatçıya Kanun tarafından yüklenen satış sonrası hizmetleri sağlama yükümlülüğü neticesinden bu yükümlülüğün eksiksiz yerine getirilebilmesi adına servis istasyonlarının verdikleri hizmetlerin denetlenmesi mümkün görülmelidir.

Bağımlılık unsurunun devamı niteliğinde olan talimat verme hususuyla alakalı bir diğer önemli nokta, adam çalıştıran sıfatının kazanılabilmesi için, söz konusu işin görülmesi noktasında emir ve talimat verme, işin teknik kısımlarına müdahale etme ve yönlendirme gibi unsurların da bulunması gerekir ${ }^{106}$. Fakat yetkili servis sözleşmelerinde, üretici/ithalatçı, servis istasyonunun yaptığı bakım-onarım gibi teknik işlerde herhangi bir talimat veremeyip müdahalede bulunamadığından, bu ilişkinin adam çalıştırma ilişkisi olduğu kabul edilemez.

\section{TBK m. 116 Açısından İnceleme}

Üretici/ ithalatçı ve servis istasyonu arasındaki ilişkinin TBK m. 66 anlamında "adam çalıştırma" ilişkisi olmadığı tespit edilmiş olup, TBK m. 116'da düzenlenen "yardımcı kişsilerin fiillerinden sorumluluk" kapsamına girip girmeyeceğinin incelenmesi gerekir. TBK m. 116'ya göre; “Borçlu, borcun ifasını veya bir borç ilişkisinden doğan hakkın kullanılmasını, birlikte yaşadı̆̆ı kişiler ya da yanında

\footnotetext{
104 4. HD. 10.04.2000, E. 2000/1199 K. 2000/3287 (Sinerji İçtihat Program1).

105 Dokutan, s. 112.

106 Yargıtay kararından bir örnek: “...bir kişinin adam kullanan kimse sayılabilmesi için, iş hayatındaki hâkim olan görüşe göre onun emretme, talimat verme veyahut denetleme kudretine haiz olmasl gerekir...” 3. HD. 03.12.1962, E. 10951 K. 9385 (Dokutan, s. 112).
} 
çalışanlar gibi yardımcılarına kanuna uygun surette bırakmış olsa bile, onların işi yürüttükleri sırada diğer tarafa verdikleri zararı gidermekle yükümlüdür". Bu kanun maddesinin dayanağı, TBK m. 83'teki, "Borcun, bizzat borçlu tarafindan ifa edilmesinde alacaklının menfaati bulunmadıkça borçlu, borcunu şahsen ifa etmekle yükümlü değildir". düzenlemesidir. Böylece Kanun'un tanımış olduğu yetki sayesinde borçlu, gerekmediği müddetçe borcunu şahsen ifa etmeyip, yardımcı kişiler kullanabilecektir ${ }^{107}$.

Kanun, borçluya, borcunu şahsen ifa etmeme imkânı tanımakla birlikte, menfaat dengesini sağlayabilmek için, yardımcı kişinin fiillerinden borçlunun kusursuz sorumluluğu esasını kabul etmiştir ${ }^{108}$. $\mathrm{Bu}$ sorumluluğun şartları ise; borçlu ile zarar gören alacaklı arasında bir borç ilişkisi bulunmalı; borçlu bu borç ilişkisinden doğan borcunun ifasını veya bir hakkın kullanılmasını yardımcı kişiye bırakmış olmalı; borcun ifası veya hakkın kullanılmasının yardımcı kişiye bırakılması mümkün olmalı; yardımcı kişinin alacaklıya verdiği zarar kendisine verilen işi yürüttüğü esnada olmalı; yardımcı kişinin davranışı, borçluya farazî bir kusur olarak yükletilebilmelidir. Ayrıca sorumluluğun genel şartlarından olan hukuka aykırı fiil sonucunda zarar meydana gelmesi ve illiyet bağının bulunması da gereklidir ${ }^{109}$.

Borçlunun sorumluluğunun doğabilmesi için kendisinin veya yardımcısının kusurunun gerekip gerekmediği ile ilgili doktrinde farklı görüşler ileri sürülmektedir ${ }^{110}$. Hâkim görüşe göre, borçlunun, yardımcı kişinin fiilinden sorumluluğunun doğabilmesi için yardımcı kişinin kusurlu olmasına gerek yoktur ${ }^{111}$. İfa veya hakkın kullanımı esnasında karşı tarafa zarar vermiş olması borçlunun sorumluluğu için yeterlidir. Kanun borçluya, adam çalıştıranın sorumluluğunda olduğu gibi kurtuluş kanıtı getirebilme imkânı da tanımamıştır. Bu sebeple, borçlunun sorumluluğu, adam çalıştıranın sorumluluğuna nazaran biraz daha ağırlaştırılmıştır. Fakat borçlunun farazî kusuruna dayanılan görüş kabul edilirse, borçlu, ifayı kendisi bizzat yapmış olsaydı bile kusurlu sayılmayacağını ispatlarsa sorumluluktan kurtulabilecektir ${ }^{12}$. Sonuç olarak, bu sorumluluk türünde, borçlunun yardımcı kişinin fiilinden sorumluluğu için, gerçek kusuru aranmayacak olup farazî kusur değerlendirmesi yapılması yeterli olacaktır.

Yetkili servis sözleşmesinde, üretici/ ithalatçı ile yetkili servis arasında TBK m. 116'daki yardımcı kişinin fiilinden sorumluluğun olup olmadığı ile ilgili uygulamada, Yargitay’ın servislerle ilgili olarak verdiği bir kararında ${ }^{113}$ şu ifadelerle, yardımcı şahıs kullanma ilişkisinin olduğunu belirtmiştir: "davalı üretici firma ile tüketici arasında malın satın alınması ile o malın en iyi şekilde bakım ve onarımının

107 von Tuhr, s. 589; Hatemi/ Gökyayla, s. 275; Kılıçoğlu, s. 818; Eren, Genel, s. 1071; Akınc1, s. 249. Bu durum doktrinde, "ifanın gayri şahsiliği ilkesi" ile ifade edilmektedir. Bkz., Eren, Genel, s. 924. Böylece, borcun borçlu tarafından şahsen ifa edilmesinin kural olmayıp, istisna olduğu belirtilmelidir. Bkz., Kılıçoğlu, s. 819. Eren, Genel, s. 1071.

Eren, Genel, s. 1072 vd.; Kılıçoğlu, s. 819 vd.; Akıncı, s. 249.

Bu görüşlerden birincisine göre, borçlunun sorumlu tutulabilmesi için yardımcı kişinin kusurunun bulunması gerekir. Diğer bir görüşe göre ise, borçlunun sorumluluğu için kendisinin veya yardımcısının kusurlu olması gerekmez. Çünkü sözleşme dişı ilişkilerde söz konusu olan adam çalıştıranın sorumluluğunun, sözleşme ilişkisinin varlığında uygulanacak hâli TBK m. 116'dır ve bu bir kusursuz sorumluluk hâlidir. Üçüncü görüş olan çoğunluk görüşüne göre ise, borçlunun sorumlu olması için yardımcı kişinin kusuru aranmaz. Hatta borçlu ve yardımcı kişinin gerçek kusuruna gerek yoktur. Sorumluluk için gerekli olan, borçlunun farazî kusurudur. Yardımcı kişinin davranışını şahsen borçlu yapmış olsaydı yine de kusurlu sayılacak idiyse artık borçlunun farazî kusurundan bahsedilebilir. Buna bağlı olarak borçlu, borcu bizzat ifa etse de kendisinin kusurlu sayılamayacağını ispatlarsa, sorumluluktan kurtulmuş olur. Bkz., Eren, Genel, s. 1082; Kılıçoğlu, s. 822; Tandoğan, Mesuliyet, s. 443 vd.; Oğuzman/ Öz, C. 1, s. 425; Tekinay/ Akman/ Burcuoğlu/ Altop, s. 898; Tunçomağ, s. 470.

111 Eren, Genel, s. 1108; Tandoğan, Mesuliyet, s. 444-446; Oğuzman/ Öz, C. 1, s. 425; Tekinay/ Akman/ Burcuoğlu/ Altop, s. 898 .

112 Borçlunun farazî kusurunu kabul eden yazarlar da, kurtuluş kanıtı getirilememesini farklı yorumlamışlardır. Bir görüşe göre, bundan bir kusursuz sorumluluk hâli doğmaktadır. Bkz., Eren, Genel, s. 1083. Diğer bir görüşe göre, kusursuz sorumluluk hâlleri, kanunda sayılanlarla sınırlı olduğundan, yardımcı şahsın fiilinden sorumluluk, kusursuz sorumluluk olarak nitelendirilemez. Bkz., Kılıçoğlu, s. 822. 
yapılması konusunda bir sözleşmenin kurulmuş olduğu görülmektedir. Bu sözleşme ile malı satın alan veya tüketici dediğimiz kişinin, bu konudaki taleplerinin davalı tarafindan değil de onun yetkili kaldiğı servis eliyle yerine getirildiğini görmekteyiz. ...Böylece yetkili servis, üreticiden aldı̆̆ yetkiye dayanarak hizmet sunmakta ve tüketici de malı satın almakla aralarında oluşan sözleşme uyarınca yetkili servisten hizmeti en iyi şekilde yerine getirmesini isteme hakkına sahip olmaktadır. ...Burada yükümlülügüüü yerine getirmekle sorumlu olan kişi, bu yükümlülüğünü bizzat değil, yardımcı kişileri kullanarak sağlamaktadır. ...BK.nun 100. maddesinde sözü edilen "yardımcı kişi" somut olayda "yetkili servis çalışanı" olarak kabul edilmeli veya en azından yetkili servis yardımo kişi gibi nitelendirilmelidir". Bir diğer kararda ${ }^{114}$ da ayn sonuca yönelik: "Davacı ile davalı üretici firma ve davalı yetkili servis arasinda sözleşme ilişkisi olduğu kabul edilerek BK'nun 100. (TBK.nun 116) maddesi gereğince zamanaşımı süresi 10 yıl olduğundan..." şeklinde bir tespit yapılmıştır ${ }^{115}$. Kararlarda görüldüğü üzere, Yargıtay, üretici/ ithalatçı ile tüketici arasında, satış sonrası hizmetlerle ilgili olarak, malın satın alınmasıyla beraber, sözleşmesel bir ilişki doğduğunu, üretici firmaların bu sözleşmeden doğan borçlarını, yetkili servis istasyonları aracılığıyla yerine getirdiklerini, bu hâlde servis istasyonlarının TBK m. 116 uyarınca yardımcı kişi sayılması gerektiği, bu mümkün olmasa bile, servis istasyonlarının çalışanlarının yardımcı kişi sayılması gerektiğini ifade etmiştir ${ }^{116}$.

Üretici/ ithalatçı, satış sonrası hizmet verme borcunu yerine getirirken, yetkili servis istasyonlarından faydalanabilecek ve durumda üretici/ ithalatçı yardımcı kişi kullanmış sayılacaktır ${ }^{117}$. Dolayısıyla, üretici/ ithalatçı, yetkili servisin fiillerinden sorumlu olacaktır ${ }^{118}$. Esasen, üretici/ ithalatçı ile yetkili servisler, TBK m. 116 hükmü olmasa bile, SSYH m. 14 gereğince, tüketiciye karşı müteselsilen sorumlu olurlar ${ }^{119}$. Yetkili servisin, üretici/ ithalatçının yardımcı kişisi sayılmasını kabul etmek, tüketici lehine bir sonuç doğuracaktır. Çünkü, burada TBK m. 116'nın uygulanması kabul edilirse, üretici kurtuluş kanıtı getiremeyecektir. Ancak, TBK m. 66'da düzenlenen adam çalıştıranın sorumluluğu kabul edilirse kurtuluş kanıtı getirme imkânı, adam çalıştıran açısından mümkün olacaktır. Yardımcı kişinin fiilinden sorumluluğu kabul etmenin tüketiciler açısından bir diğer lehe olan sonucu, zamanaşımı hususundadır. TBK m. 66'ya dayanan tazminat talepleri, TBK m. 72 gereği haksız fiillere uygulanan zamanaşımı olan iki ve on yıllık sürelere tâbi iken, TBK m. 116'ya dayanan tazminat talepleri, alacaklara ilişkin zamanaşımı düzenlemesi olan TBK m. 146 gereğince on yıllık zamanaşımına tabi olacaktır ${ }^{120}$.

Yetkili servisin, yardımcı kişi olarak borcun ifasında görev alması durumunda, teknik bilgi olarak daha uzman başka bir yetkili servisi kullanması, bu konuda yetkisi varsa mümkündür. Bu hâlde, ikinci yetkili servis, borcun ifasında ikame kişi sayılır. TBK m.502/2 atfi gereğine, yetkili servis sözleşmesinin niteliğine uygun düşen vekâlet hükümleri bu sözleşmeye uygulanacaktır. Böylece, ilk yetkili servis, ikinci (ikame) yetkili servisin üretici/ ithalatçıya verdiği zararlardan, TBK m.116'ya göre değil, TBK m.507/2'ye

\footnotetext{
114 3. HD. 10.03.2015, E. 2014/8622 K. 2015/3846 (Sinerji İçtihat).

115 Yargıtay’ın, üretici ile yetkili servis istasyonu arasındaki ilişkiyi yardımcı kişi kullanma olarak değerlendirmesiyle ilgili örnek kararlar için bkz.: 13. HD. 23.02.2007, E. 2006/14233 K. 2007/2558 (Kazanc1 İçtihat); 3. HD. 10.03.2015, E. 2014/8622 K. 2015/3846 (Sinerji İçtihat).

$116 \quad$ Aydoğdu, s. 184.

117 Servis hizmeti sunma, şahsî edim niteliği taşımadığından, üretici/ ithalatçılar tarafından bizzat yerine getirilmesi gereken bir borç değildir. Bkz., Uyumaz, s. 331.

118 Uyumaz, s. 323.

119 Uyumaz, s. 323.

120 Dokutan, s. 114
} 
göre sorumlu olacaktır ${ }^{121}$. Bununla birlikte, yetkili servis, kaim vekil dışında bir olağan yardımcı kullandığında, bu yardımcının verdiği zararlardan TBK m. 116 gereğince sorumlu olur ${ }^{122}$.

\section{YETKİLI SERVIS İLE TÜKETİCI ARASINDAKİ İLIŞKİ}

Yetkili servis ile tüketici arasındaki ilişkinin belirlenmesinde, önemli olan, tüketicinin, malla ilgili herhangi bir sorunda, hangi dönemde servis istasyonlarına müracaat ettiğidir. Eğer tüketici, maldaki ayıp veya arızada, garanti süresi içerisinde servis istasyonlarına gitmiş ise, bu hâlde iki taraf arasında sözleşmesel bir ilişkiden bahsedilemeyecek olup, tüketici garanti belgesine veya Kanun'a dayanarak üretici/ ithalatç1/ satıcıdan talepte bulunabilecektir. Bu durumda da, tüketicinin servis istasyonuna karşı herhangi bir ödemede, ifada bulunması söz konusu değildir ${ }^{123}$. Dolayısıyla tüketicinin, aralarındaki sözleşmeden dolayı taleplerde bulunabileceği tarafın servis istasyonu olmayıp, üretici/ ithalatçı/ satıcı olduğu ifade edilmelidir. Buna rağmen, yetkili servis sözleşmesinin tam üçüncü kişi yararına sözleşme olduğundan, bu sözleşmeye dayanarak tüketicinin, edimin ifası için doğrudan servis istasyonunu muhatap alarak ondan talepte bulunabilmesi mümkündür. Bu hâlde tüketici, üçüncü kişi yararına sözleşmelerin bir özelliği olarak sözleşmenin tarafi olmamakla birlikte sözleşmeye dayanarak bazı haklar elde edebilmektedir. Ancak, tüketicinin yetkili servis istasyonuna karşı ileri sürebileceği bu haklar, ürünün montajı, bakım-onarımı ile sınırlı olup, sözleşmeden dönme, bedel iadesi gibi taleplerin muhatabı yetkili servis değildir.

Tüketicinin garanti süresi dışında (garanti kapsamı haricinde) servis istasyonlarına başvurduğu hâllerde, artık üretici/ ithalatçı için bir sorumluluk doğmayacağından, servis istasyonuyla tüketici doğrudan muhatap olmakta ve aralarında sözleşmesel bir ilişki meydana gelmektedir. Bu sözleşme, tüketicinin getirdiği malın, servis istasyonunca bakım ve onarımını konu edinen bir eser sözleşmesidir. Böylece taraflar arasındaki ilişkinin kapsamında ortaya çıkacak hak, yükümlülük ve sorumluluklar, bu sözleşmeye göre belirlenecektir ${ }^{124}$

Tüketici ve yetkili servisler arasındaki ilişkide, değinilmesi gereken bir diğer husus, servis istasyonlarının tüketiciye herhangi bir zarar vermeleri hâlidir. Servis istasyonlarının hukuka aykırı fiilleriyle, kusurlu şekilde tüketiciye zarar vermeleri, onu zarara uğratmaları hâlinde artık aralarında sözleşme ilişkisinin olup olmadığına bakılmaksızın TBK m. 49 vd. düzenlenen haksız fiil hükümlerine göre sorumluluk tayin edilecektirr ${ }^{125}$. Tüketici, satış sonrası hizmet nedeniyle bir zarara uğradığında, ister sözleşmeye dayanan taleplerde bulunabilecek isterse haksız fiil hükümlerine dayanabilecektir ${ }^{126}$.

\section{YETKILİ SERVISLERIN VERDIKLERI HIZMETTEN DOĞAN SORUMLULUĞU}

Yetkili servisler, sundukları hizmet gereği, öncelikle tüketicinin bakım-onarım için getirdiği malları güvenli şekilde muhafaza edip, maldaki sorun ve arızanın tespiti için gerekli incelemeleri yaptıktan sonra, tüketiciyi zarara uğratmayacak biçimde malın bakım ve onarımını yapmalıdır. Servis istasyonunun bu bakım-onarım esnasında, tüketiciye verdiği zarardan kimlerin sorumlu olduğu tespit edilmesi gerekir. Kanun'da tüketiciye ücretsiz onarım hakkının tanınmış olması, ayıplı maldan sorumluluk kapsamında tüketici lehine iken, malın onarımı esnasında sunulan hizmetin kötü olması nedeniyle yeni mağduriyetler

121 Buna göre, yetkili servis, sadece ifada yetki verdiği diğer yetkili servisi seçmede ve talimat vermede gerekli özeni göstermek zorundadır (TBK m.507/2).

122 Uyumaz, s. 329.

123 Dokutan, s. 116.

124 Çelik, Yağmur Esin. "Satış Sonrası Hizmetler", 6502 sayılı Tüketicinin Korunması Hakkında Kanun Hükümlerine Göre Tüketici Hukuku Uygulamalarında Tüketicinin Korunması (Ed. Sert Sütçü, Selin), Ankara 2019, s. 131; Dokutan, s. 116.

125 Dokutan, s. 117

126 Sözleşmeden doğan talepler ile haksız fiil hükümleri yarışsa da, imkân varsa sözleşmeden doğan taleplere dayanmak, zarar ve kusurun ispatı, zamanaşımı gibi hususlar açısından tüketicinin lehinedir. 
oluşabilecektir. Sorumluluk da bu durumda önem kazanarak, oluşan zararların tazmini hususunda bir yol haritası çizer. Zira, doktrinde ifade edildiği gibi sorumluluk, borcun yaptırımıdır ${ }^{127}$.

Zarar kavramı, burada iki yönden değerlendirilecek olup bunlardan birisi, ayıp zararı denilen kavram, diğeri ise ayıbın neden olduğu dolaylı zarar kavramıdır. Ayıp zararı, ifa menfaatinde oluşan kayıp şeklinde tanımlanabilir. Bunlara örnek olarak, onarım masrafı, muayene masrafı vb. verilebilir. Ayıbın neden olduğu dolaylı zararlar ise, ayıplı mal nedeniyle uğranılan ve ayıbı takiben oluşan zararlardır ${ }^{128}$. Üreticinin sorumluluğunda olduğu gibi, burada da sorumluluk sözleşmeye dayanan şekilde veya haksız fiil nedeniyle ortaya çıkabilecek bir sorumluluktur. Üreticinin sorumluluğu esas olarak, ayıplı malın neden olduğu (refakat ettiği) zararlar bağlamında kendini gösterebilecekken, yetkili servis sorumluluğu da buna paralel şekilde, ayıbın neden olduğu zararlar konusunda önem arz edecektir ${ }^{129}$.

\section{Garanti Süresi İçindeki Sorumluluğu}

Tüketicinin Korunması Hakkında Kanun m. 56’ya göre üretici/ ithalatçılar, sattıkları mallarla ilgili olarak, içeriği yönetmelikte belirlenen garanti belgesini düzenlemek zorundadırlar. Satıcılar ise bu belgenin tekemmül ettirilip tüketiciye verilmesinden sorumludurlar. Bu belirtilen zorunlu garanti belgesidir. Bir de yine Kanun'un 57. maddesine dayanılarak, tüketicinin kanunî hakları saklı kalmak kaydıyla, satıc1, üretici, ithalatçı veya sağlayıcı tarafından; onarım, bakım, değişim, bedel iadesi vb. hususlarda ilave taahhütlerde bulunulabilmesi mümkündür ${ }^{130}$. Garanti belgesinin düzenlendiği hâlde, TKHK m. 11'den farkl1 olarak, tüm seçimlik haklar satıcı, üretici veya ithalatçıya karşı kullanılabilecektir. TKHK m. 56/3 böyle bir düzenleme öngörmese idi, m. 11'e dayanarak ancak ücretsiz onarım ve değişim hakları satıcı, üretici veya ithalatçıya karşı kullanılabilecek, diğer haklar sadece satıcıya karşı kullanılabilecekti1 ${ }^{131} .4077$ sayılı TKHK m. 4, tüketici karşısındaki sorumluları (satıc1, üretici, bayi, acente, ithalatçı), yürürlükteki TKHK'ya göre geniş tutmuştur ${ }^{132}$

6502 sayılı TKHK'ya göre seçimlik hakların muhatabı ilk etapta satıcıdır. Yukarıda da ifade edildiği gibi ücretsiz onarım veya değişim hakları bakımından muhataplar ise, satıcı yanında üretici veya ithalatçı da olabilecektir. Uygulamada sıklıkla görüldügü üzere, ücretsiz onarım veya değişim gibi hakların kullanımında tüketiciler, servis istasyonlarına başvurmaktadırlar. Servis istasyonu kurarak satış sonrası hizmet verme borcu üretici/ ithalatçılara yüklendiğinden, istasyonlara yapılan başvuru üretici/ ithalatçıya yapılmış sayılacaktır çünkü Yargıtay'ın da kabul ettiği gibi, servis istasyonları üretici/ ithalatçıların ifa yardımcısı konumundadır ${ }^{133}$. Bununla ilgili olarak garanti süresi içinde malda çıkan ayıplar ve arızalardan veyahut bakım işleminden satış sonrası hizmetler kapsamında üretici/ ithalatçının sorumlu olup bu hizmeti servis istasyonları aracılığı ile yerine getirdikleri yukarıda ifade edilmişti ${ }^{134}$. Burada tüketici ile servis istasyonları arasında herhangi bir sözleşme de olmadığından, servis istasyonunun ayıplı mal ve arızalardan

\footnotetext{
$127 \quad$ Eren, Genel, s. 83.

128 Arbek, s 221; Dokutan, s. 127; Tarman, Zeynep Derya. Türk Hukukunda İmalatçının Sorumluluğuna Genel Bir Baklş, http: // www. journals. istanbul. edu. tr/ iuhfm/ article/ download/ 1023003858/1023003448 (Et: 03.04.2018), s. 317.

129 Tarman, s. 300.

130 Özel, s. 279.

$131 \quad$ Aydoğdu, s. 101.

132 Özdemir/ Sarı, s. 19; Akçaal, Mehmet/ Uyumaz, Alper. "6502 sayılı Tüketicinin Korunması Hakkında Kanunun Bazı Hükümlerine İlişkin (m. 1-16) Bir İnceleme”, Inönü Üniversitesi Hukuk Fakültesi Dergisi, C. 4, S. 2, 2013, s. 241-276, s. 263; Mccarthy, Oya Şahin. "6502 sayılı Tüketicinin Korunması Hakkında Kanun Genel Çerçevesi ve 4077 sayılı Eski Yasa ile Kıyaslama”, İstanbul Barosu Dergisi, C. 88, Özel Sayı, 2014, s. 149.

133 Aydoğdu, s. 104; 3. HD. 10.03.2015, E. 2014/8622 K. 2015/3846 (Sinerji İçtihat).

134 Bkz., I, A.
} 
sorumluluğunun bulunmadığı ifade edilmelidir. Çünkü satılan maldaki ayıptan dolayı servis istasyonlarının herhangi bir sorumluluğu yoktur.

Servis istasyonunun sorumluluğu, ayıplı hizmet konusunda ortaya çıkmaktadır. TKHK m. 13 ve 14'te, ayıplı hizmetten sorumluluk düzenlenmiştir. Yetkili servis istasyonu, malın onarımı faaliyeti esnasında bir zarara sebebiyet verirse bu ayıplı hizmet sayılacak ve sorumluluk söz konusu olacaktır ${ }^{135}$. Burada sorumlu olanlar her şeyden önce, SSHY m. 14'e göre üretici veya ithalatçılardır. Çünkü satış sonrası hizmeti sağlama yükümlülüğü üretici veya ithalatçının üzerindedir. Maddedeki ifadede, "servis istasyonlarının ayrı bir tüzel kişiliği olsa dahi, satış sonrası hizmetlerin sağlanmasından ve yürütülmesinden yetkili servis istasyonları ile birlikte müteselsilen sorumludur" denilerek, üretici, ithalatçı ve servis istasyonları müteselsil sorumlu kılınmıştır. Burada üretici veya ithalatçının sözleşmesel bir sorumluluğu bulunmaktadır. Servis istasyonları da, üretici/ ithalatçı ile yaptıkları yetkili servis sözleşmesi gereği tüketiciye karşı üçüncü kişi yararına sözleşme kapsamında sorumlu olacak, ayrıca servisler kusurlarıyla verdikleri zarardan haksız fiil esaslarına göre sorumlu tutulabileceklerdir.

Ayıplı malların neden olduğu zararlar, 4077 sayılı Kanun döneminde çıkarılan "Ayıplı Malın Neden Olduğu Zararlardan Sorumluluk Hakkında Yönetmelik” m. 6' da “Ayıplı bir malın, bir kişinin ölümüne veya yaralanmasına veya bir malın zarar görmesine sebep olması hâlinde imalatçı/üretici doğan zararı, kusuru aranmaksızın tazmin etmekle yükümlüdür" şeklinde kusursuz bir sorumluluk olarak düzenlenmiştir ${ }^{136}$. Toplumdaki algıya bakıldığında da, ayıplı malın sebep olduğu zararlar, genellikle üretim hataları sonucu meydana geldiğinden, ilk olarak üreticilerin sorumlu tutulması hakkaniyete uygun görünmektedir ${ }^{137}$. Üreticinin sorumlu tutulmasındaki maksat, güvenli olmayan, tehlike arz eden ürünlerin piyasaya sürülmesine engel olunarak herhangi bir zararın ortaya çıkmamasını sağlamaktır ${ }^{138}$. İleri teknoloji sayesinde artan ürün çeşitliliğinin faydalarının yanında, beklenmedik zararların da meydana gelebileceği göz önüne alındığında, üreticinin kusursuz sorumluluğuna gitmek, çağdaş teknik üretimin yapısında bulunan rizikolara karşı en uygun çözümü ifade etmekte ve tüketici/ kullanıcıların mağduriyetlerini gidermede önemli rol oynamaktadır ${ }^{139}$.

Yürürlükte bulunan 6502 sayılı Kanun ve ona bağlı yönetmeliklerde ise, ayıplı malın neden olacağı zararla ilgili açık bir düzenleme yapılmamıştır. Kanun'un 58. maddesinin 4. fikrasında üretici/ ithalatçıların satış sonrası hizmetleri sağlarken, servis istasyonlarının verdiği hizmetten sorumlu oldukları belirtilmiştir. Buna dayanarak servis istasyonlarının bu hizmet esnasında verdikleri zararlardan da üretici/ ithalatçı sorumlu olacaktır ${ }^{140}$. Servis istasyonunun haksız fiile dayanan sözleşme dışı sorumluluğu ise ayrıca değerlendirilmelidir. Böylece, müteselsil sorumluluğun bir türü olan, aynı zarardan birden fazla kişinin

135 Aydoğdu, s. 194; Özel, s. 128; Tiryaki, Betül. Tüketicinin Korunması Hukuku Açısından Ayıplı Hizmetten Doğan Sorumluluk, https: // tez. yok. gov. tr/ UlusalTezMerkezi/ tezSorguSonucYeni. jsp, (Et: 02.03.2018), s. $117 \mathrm{vd}$.

136 Özel, s. 124. Söz konusu Yönetmelik, 4077 sayılı Kanun’a dayanılarak çıkarılsa da, 6502 sayılı Kanun'un geçici birinci maddesinin üçüncü fikrasına göre, bu Kanun'a dayanarak çıkarılacak yönetmelikler yürürlüğe girene kadar, kaldırılan Kanun'a dayanarak çıkarılmış yönetmeliklerin bu Kanun'a aykırı olmayan hükümleri uygulama alanı bulacaktır. Bu sebeple, Ayıplı Malın Neden Olduğu Zararlardan Sorumluluk Hakkında Yönetmelik hükümleri hâlen uygulama alanı bulan hükümlerdir. Bununla birlikte, 6502 sayılı Kanun m. 84/II'ye göre, bu Kanun'da öngörülen yönetmelikler, Kanun'un yürürlüğe girdiği tarihten itibaren altı ay içinde Bakanlık tarafından çıkarılmalıdır. Dolayısıyla, ayıplı malların neden olduğu zararlarla ilgili bir yönetmeliğin çıkarılması ve eski yönetmeliğin yürürlükten kaldırılması uygun olacaktır. Y1lmaz, s. 134.

138 Dokutan, s. 128;

139 İnal, H. Tamer. Tüketici Hukuku, 3. Baskı, Seçkin Yayıncılık, Ankara 2014, s. 391.

140 HGK. 08.07.2009, E. 2009/4-291 K. 2009/318, (Kazancı İçtihat); 13. HD. 13.12.2016, E. $2015 / 13811$ K. 2016/23199, (Kazancı İçtihat). 
sorumluluğu söz konusu olacaktır (TBK m. 61) ${ }^{141}$. Yine, TKHK m. 11/6'nın TBK'ya yaptığı atıf sayesinde, ayıplı malın neden olduğu zararlardan dolayı satıcı, üretici veya ithalatçının sorumluluğuna gidilebilir. Servis istasyonlarının, söz konusu maddelerde müteselsil sorumlu olarak sayılmamış olması, onun sorumluluğuna gidilmeyeceği anlamına gelmez. Özellikle servis istasyonlarının kusurlarıyla verdikleri zararlarda haksız fiil sorumlulukları gündeme gelebileceği gibi, üretici ile servis istasyonu arasında yapılan yetkili servis sözleşmesinin tam üçüncü kişi yararına sözleşme niteliğinde olmasından ötürü, satış sonrası hizmetlerin sunulmasıyla alakalı, tüketicinin taleplerine karşı yetkili servis istasyonlarının da sözleşmesel sorumluluğu söz konusu olabilecektir. Üretici/ ithalatçı ise, satış sonrası hizmet borcunun ifasında servis istasyonunu yardımcı kişi olarak kullandığı için yukarıda da belirtildiği üzere, TBK m. 116 gereğince sorumlu olacaktır ${ }^{142}$.

Üretici/ ithalatçılar, yetkili servislerin faaliyetlerinden sorumlu olsalar da, satış sonrası hizmetlerin mevzuata uygun yürütülmesi için gerekli önlemleri alarak, istasyonlardaki eksiklikleri giderip bu yerleri kontrol ettiklerini ispatlayarak, servis istasyonlarının edimini gereği gibi yerine getirmeyip tüketiciye zarar verdiği hâllerde, TBK m. 62 gereği istasyona rücu edebilecektir. Böylece, üretici/ ithalatçların da sorumluluktan kısmen veya tamamen kurtulabilmeleri imkânı söz konusudur ${ }^{143}$.

\section{Garanti Süresi Dişindaki Sorumluluğu}

$\mathrm{Bu}$ kısımda hem yetkili servislerin garanti süresi dışındaki sorumluluğu incelenecek hem de bunun yanında, servis hizmeti vermekle beraber üretici/ ithalatçıyla arasında yetkili servis sözleşmesi bulunmayan bağımsız (anlaşmasız özel servis) servisin sorumluluğuna değinilecektir.

Garanti süresi dolduğunda, tüketici için muhatap doğrudan servis istasyonları olmaktadır ${ }^{144}$. Tüketici, mal ile ilgili arızaların onarımı veya bakımı için doğrudan servis istasyonlarına müracaat edecek ve bu hâlde aralarında karşılıklı bir hukukî ilişki olacaktır. Bu hukukî ilişkinin konusu, tüketicinin servis istasyonuna getirdiği malın bakım veya onarımıdır. Tarafların bedel karşılığında bir malın bakım veya onarımı konusunda anlaşmaları eser sözleşmesidir ${ }^{145}$. Yukarıda ifade edildiği üzere, tüketicinin garanti kapsamı dışında, servis istasyonuna, malın ücret karşılığında onarımı veya bakımı için başvurması ve tarafların bu konuda anlaşmaları üzerine eser sözleşmesi kurulmuş olur ${ }^{146}$. Yargıtay da tüketici ve servis istasyonu arasındaki ilişkiyi eser sözleşmesi olarak kabul etmektedir ${ }^{147}$. Buna göre, herhangi bir üretici veya ithalatçıya bağlı olmadan hizmet vererek faaliyette bulunan servis istasyonları bu hizmetleri sebebiyle tüketiciye karşı sorumlu olacaklardır ${ }^{148}$. Bu sorumluluğun kaynağı iki ayrı nedene dayanmaktadır: Bunlardan ilki tüketici ve servis istasyonu arasındaki eser sözleşmesidir. Eser sözleşmesi sayesinde, tüketici ile servis arasında sözleşmesel bir bağ oluşmaktadır. Diğer sorumluluk nedeni ise, TBK m. 49 bağlamında haksız fiil sorumluluğudur. Eğer servis istasyonu, kusurlu ve hukuka aykırı hareketiyle tüketiciye herhangi bir zarar vermiş ise haksız fiil sorumluluğuna gidilecektir. Burada sözleşmeden doğan sorumluluk ile haksız fiil sorumluluğu hükümleri yarışır. Tüketici açısından avantajlı olan, ispat yükü, zamanaşımı süresi gibi hususlardan dolayı sözleşmeden doğan sorumluluğa dayanmaktır.

Garanti süresi dışındaki sorumlulukta, sorumluluğun esası, bağımsız servis istasyonunun ayıplı hizmeti nedeniyle verdiği zarara dayandığından, bu hâlde, satıcı, üretici veya ithalatçıyı sorumlu tutmak mümkün değildir. Dolayısıyla onların bu konuda müteselsil sorumluluğundan bahsedilemeyecektir.

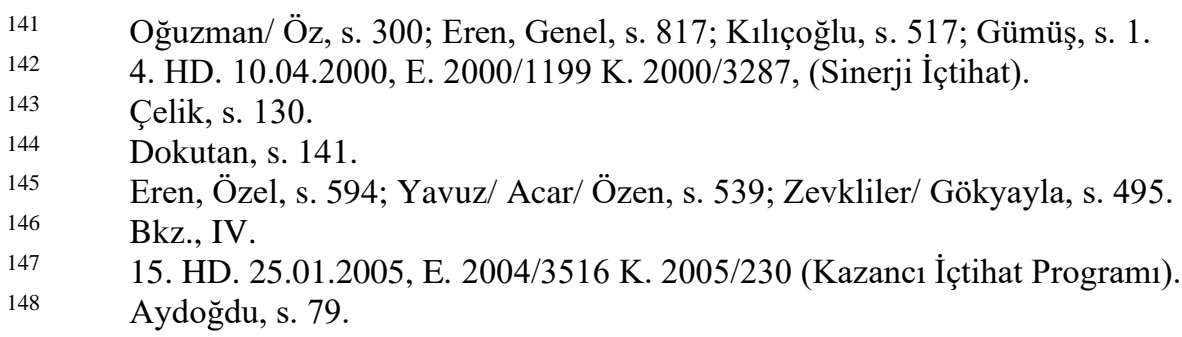


Bağımsız servis istasyonlarına garanti süresi içinde başvurulsa dahi, bu tüketicinin hatası sayılacak ve üretici/ ithalatçılar müteselsil sorumlular zincirine dâhil edilemeyecek, tüketici karşısındaki tek sorumlu, zararı meydana getiren bağımsız (yetkisiz) servis istasyonu olacaktır ${ }^{149}$.

Son olarak ifade edilmelidir ki garanti süresi dışında, servis istasyonları tarafından verilen bakım, onarım, montaj hizmetleriyle ilgili bir yıl içerisinde aynı arıza tekrar ederse, tüketiciden herhangi bir şekilde ücret talep edilemeyecektir (SSHY m. 10/6) ${ }^{150}$.

\section{Müteselsil Sorumluluk (Birden Çok Kişinin Ayni Zarardan Sorumlu Olmasi) Ve Rücu İlişkisi}

Satış Sonrası Hizmetler Yönetmeliği m. 14'e göre, üretici veya ithalatçılar ile yetkili servis istasyonları, satış sonrası hizmetlerin yerine getirilmesinden müteselsil sorumludur. Müteselsil sorumluluk, birden çok kişinin birlikte bir zarara sebep olması ya da aynı zarardan farklı sebeplerle sorumlu olmaları hâlinde uygulanır ${ }^{151}$.

Müteselsil sorumlulukta her borçlunun sorumluluk sebebi aynı olabileceği gibi farklı sebeplere de dayanabilir. Örneğin, bir diz üstü bilgisayarın fanlarının temizlenmesi, ram belleği ve dâhili belleğinin arttırılması için ayrı bir tüzel kişiliği olan (Y) yetkili servis istasyonuna bırakılmıştır. (Y) firmasının çalışanı (T), fanları temizleyip ram ve dâhili bellekleri istenilen şekilde arttırdıktan sonra, bilgisayara format atmış ve yazılım güncellemesi yapmıştır. Bu işlemleri yaptıktan sonra da kontrol amacıyla kendi cep telefonunu bilgisayara bağlamış ve bilgisayara bir tür zararlı yazılım bulaşmıştır. Bilgisayar tamirden sonra sahibi (A)'ya teslim edilmiş ve (A) bilgisayarı kullanırken içindeki zararlı yazılımdan dolayı bankacılık ile ilgili verileri çalınmış ve ayrıca bilgisayarı bağladığı televizyonunda piksel kaybı yaşamıştır. (A)'nın uğradığı bu zararlar, ayıplı malın bakımıyla ilgili yani ayıplı hizmet nedeniyle oluşan zararlardır. Bu zararlardan sorumlu olanlar; en başta kanun gereği sorumlu tutulan üretici/ ithalatçıdır. Ayrıca, ürünü kendi tüzel kişiliği altında bakım/ onarıma yetkili olan servis istasyonu (Y) de hem TKHK m. 14 ve SSYH m. 14 gereği hem de yardımcı kişi olarak (T)'yi kullandığından TBK m. 116 gereği sorumludur. Ayrıca çalışan (T), kusuruyla verdiği zarardan haksız fiil hükümlerine göre sorumlu olacaktır ${ }^{152}$. Bununla birlikte (A), her ne kadar üretici/ ithalatçı ile yetkili servis arasındaki yetkili servis sözleşmesinin tarafı olmasa da, bu sözleşmenin tam üçüncü kişi yararına sözleşme olmasından dolayı, hizmetin tam ve doğru bir şekilde yerine getirilmesini, bu sözleşmeye dayanarak servis istasyonundan talep edebilecektir.

Örnekte müteselsil sorumluluk söz konusu olduğundan, tüketici (A), uğradığı zararın tazmini için (Y), (T) veya üretici/ ithalatçıdan herhangi birine başvurabilir (TBK m. 61). Sorumlulardan biri, zararın tamamını tazmin ettiğinde, kendi payına düşen kısımdan fazlasını diğer sorumlulardan rücu ilişkisi kapsamında talep edebilir ve zarar görenin haklarına halef olur (TBK m. 62). Burada, sorumlular arasında maddî yönden en güçlü olan taraftan talepte bulunmak daha avantajlıdır. Dolayısıyla, tüketici açısından zararın tazmini talebinin üretici/ ithalatçıya yöneltilmesi, zararın çabuk giderilmesi açısından yerinde olacaktır.

\section{SONUÇ}

Uygulamada sıkça rastlanılan yetkili servis istasyonları, satış sonrası hizmetler organizasyonunun önemli bir parçasıdır. Satış sonrası hizmetleri sunmakla yükümlü olanlar üretici veya ithalatçılardır. Bu konuda, servis istasyonlarının bir yükümlülüğü söz konusu değildir. Servis istasyonunun malda ayıp

\footnotetext{
149 Dokutan, s. 195. Bununla birlikte, üretici veya ithalatçılar, bağımsız servis istasyonlarıyla da belli anlaşmalar yaparak tüketiciye karşı müteselsil sorumlu hâle gelebilirler.

150 Özel, s. 282.

151 Eren, Genel, s. 834; Oğuzman/ Öz, C. 2, s. 299; Kılıçoğlu, s. 586; Antalya, O. Gökhan. Borçlar Hukuku Genel Hükümler, C. 2, Legal Yayınc1lı, İstanbul 2017, s. 548; Tunçomağ, s. 331 vd. 
bulunmasından da bir sorumluluğu bulunmamaktadır. Burada tartışılan, ayıplı malla ilgili onarım borcunun ifasında yapılan, düzgün bir ifaya aykırı hareketler ve oluşan zararlar sonucu servisin sorumlu tutulup tutulamayacağıdır. Servis istasyonları, üretici veya ithalatçıların satış sonrası hizmet verme borcunu ifa ederken kullandıkları TBK m. 116 anlamında ifa yardımcısı konumundadırlar. Bu sebeple, oluşabilecek zararlardan, üretici veya ithalatçının tüketiciye karşı sözleşmesel sorumluluğu bulunmaktadır. Yetkili servisler ise, onarım borcunu gereği gibi ifa etmeyerek tüketiciye zarar verdiklerinde, bu zarardan hem sözleşmeye göre hem de haksız fiil hükümlerine göre sorumlu olur. Zira, üretici/ ithalatçı ile yetkili servis sözleşmesi arasında bulunan sözleşmenin tam üçüncü kişi yararına sözleşme olması sonucunda, tüketici, doğrudan yetkili servisten tam ve gereği gibi bir ifayı talep edebilir. Ayrıca yetkili servislerin, zararın doğmasıyla ilgili olarak, haksız fiilin tüm unsurlarıyla mevcut olması hâlinde sözleşme dışı sorumlulukları da söz konusudur. Bu hâlde tüketici, dilerse doğrudan haksız fiil hükümlerine göre yetkili servis istasyonuna, dilerse sözleşme sorumluluğuna dayanarak üretici/ ithalatçı veya yetkili servisin sorumluluğuna gidebilir. Tüketicinin bu durumda sözleşmeden doğan sorumluluğa dayanması, ispat yükünden kurtulma ve zamanaşımı süresinin uzunluğu gibi sebeplerle daha avantajlıdır. Ayrıca uygulamada üretici/ ithalatçıların daha büyük firmalar olduğu göz önüne alındığında, yetkili servis yerine doğrudan üretici/ ithalatçıdan talepte bulunulması tüketicinin lehinedir.

Garanti süresi dışında ise, tüketici doğrudan servis istasyonlarıyla muhatap olduğundan ve üretici/ ithalatçının sözleşme sorumluluğu sona erdiğinden, oluşabilecek zararlarla ilgili olarak sadece ayıplı hizmette bulunan servis istasyonunun sorumluluğuna gidilebilecektir. Bu da yine haksız fiile ve sözleşmeye dayanan (eser sözleşmesi) sorumluluk şeklinde iki ayrı sebebe dayanacak olup, avantajlı olan sözleşme sorumluluğuna yönelmek mantıklı bir tercih olacaktır. Yine de, üretici veya ithalatçı firmaların, servis istasyonlarına nazaran daha büyük firmalar oldukları göz önüne alınırsa, imkân olduğu müddetçe taleplerin üretici veya ithalatçıya yöneltilmesi, tüketicinin mağduriyet yaşamaması açısından daha doğru olacaktır.

\section{KAYNAKÇA*}

Akçaal, Mehmet/ Uyumaz, Alper. "6502 sayılı Tüketicinin Korunması Hakkında Kanunun Bazı Hükümlerine İlişkin (m. 1-16) Bir İnceleme”, İnönü Üniversitesi Hukuk Fakültesi Dergisi, C. 4, S. 2, 2013, s. 241-276.

Akınc1, Şahin. Borçlar Hukuku Bilgisi, 10. Baskı, Sayram Yayınları, Konya 2017.

Akıncı, Şahin. Vekâlet Sözleşmesinin Sona Ermesi, Sayram Yayınları, Konya 2004 (Vekâlet).

Akünal, Teoman. "Onarım Garantisi”, İstanbul Üniversitesi Hukuk Fakültesi Mecmuası, C. 38, S. 1-4, 1973, s. 547-570.

Aktürk Yücer, İpek. İsimsiz Sözleşme Genel Teorisi ve Uzaktan Öğretim Sözleşmesi, Yetkin Yayınları, Ankara 2016

Antalya, O. Gökhan. Borçlar Hukuku Genel Hükümler, C. 1, Legal Yayınevi, İstanbul 2018.

Antalya, O. Gökhan. Borçlar Hukuku Genel Hükümler, C. 2, Legal Yayıncılık, İstanbul 2017 (C. 2).

Aral, Fahrettin/ Ayrancı, Hasan. Borçlar Hukuku (Özel Borç İlişkileri), 11. Baskı, Yetkin Yayınevi, Ankara 2018.

Arbek, Ömer. Satım Konusu Ayıplı Malın Tamir Edilmesi, Yetkin Yayınları, Ankara 2005.

Aslan, İ. Yılmaz. Tüketici Hukuku Dersleri, 6. Bask1, Ekin Yayınevi, 2016.

Aslan, Bayram. "Onarım Borcunun İfa Edilmesi”, Selçuk Üniversitesi Hukuk Fakültesi Dergisi, C.25, S.1, 2017 (Onarım).

Atabek, Reşat. "İmalatçının Üçüncü Kişilere Karşı Sorumluluğu”, BATIDER, C. 10, S. 1, Haziran 1979, s. 159175.

Atamer, Yeşim M./ Baş, Ece. “Avrupa Birliği Hukuku ile Karşılaştırmalı Olarak 6502 Sayılı Yeni Tüketicinin Korunması Hakkında Kanun Uyarınca Satım Sözleşmesinde Ayıptan Doğan Sorumluluk”, İstanbul Barosu Dergisi, C. 88, Özel Sayı, 2014.

Aynı yazarın birden fazla eserine atıf yapılan hallerde, karışılık olmaması adına, her eserin sonuna o eserle ilgili kısaltma eklenerek ayrım yapılmıştır. 
Aydoğdu, Murat/ Kahveci, Nalan. Türk Borçlar Hukuku Özel Borç İlişkileri, 4. Baskı, Adalet Yayınevi, Ankara 2019

Aydoğdu, Murat. Tüketici Hukuku Dersleri, Adalet Yayınevi, Ankara 2015.

Başpınar, Veysel. “Avukatlık Sözleşmesi ve Ücreti Hakkında Bazı Düşünceler”, Ankara Barosu Hukuk Kurultayl, C. 3, 2004, s. 463-478.

Baykan, Renan. Tüketici Hukuku Mevzuata İlş̧kin Yorum Eleştiri Öneri, 2. Bask1, İstanbul Ticaret Odası Yayınlar1, 2005.

Becker, H. Isviçre Medenî Kanunu Şerhi VI. Cilt Borçlar Kanunu, IV. Fasikül, Ankara Yarı Açık Cezaevi Matbaası, Ankara 1972 (Çev: Saim Özkök).

Bucher, Eugen. Schweizerisches Obligationenrecht, 2., neubearbeitete und erweiterte Auflage, Schultess Verlag, Zürich 1988.

Çelik, Yağmur Esin. "Satış Sonrası Hizmetler”, 6502 sayılı Tüketicinin Korunması Hakkında Kanun Hükümlerine Göre Tüketici Hukuku Uygulamalarında Tüketicinin Korunması (Ed. Sert Sütçü, Selin), Ankara 2019.

Çınar Ural, Nihal. Tüketicinin Korunması Hakkında Kanun'a Göre Ayıba Karşı Tekeffül, https://tez. yok. gov. tr/ Ulusal TezMerkezi/ tezSorguSonucYeni. jsp, (Et: 04.04.2018).

Dokutan, Canan. Tüketici Hukuku Bakımından Ayıplı Ifa Çerçevesinde Bayi ve Servisin Sorumluluğu, https://tez.yok.gov.tr/UlusalTezMerkezi/tezSorguSonucYeni.jsp, (Et: 16.03.2018).

Emiroğlu, Haluk. "Roma Hukuku'nda Vekâlet Sözleşmesi (Mandatum) ve Hukuki İşlemlerde Temsil”, Ankara Üniversitesi Hukuk Fakültesi Dergisi, C. 52, S. 1, 2003, s. 101-111.

Eren, Fikret. Borçlar Hukuku Genel Hükümler, 23. Baskı, Yetkin Yayınları, Ankara 2018 (Eren, Genel).

Eren, Fikret. Borçlar Hukuku Özel Hükümler, Yetkin Yayınevi, 6. Baskı, Ankara 2018.

Eren, Fikret. "İsimsiz Sözleşmelere İlişkin Bazı Sorunlar”, Turgut Akıntürk’e Armăgan, Beta Yayınevi, 2008, s. 85-111.

Feyzioğlu, Necmeddin F. Borçlar Hukuku Genel Hükümler, C. 1, İstanbul Üniversitesi Hukuk Fakültesi Yayınları, İstanbul 1976.

Feyzioğlu, Necmeddin F. Borçlar Hukuku Hususî Kısım Akdin Muhtelif Nevîleri, C. 1, İstanbul Üniversitesi Hukuk Fakültesi Yayınları, İstanbul 1970.

Göçer, Ahmet Alpaslan. Garanti Belgeleri, http: // acikerisim. selcuk. edu. tr: 8080/ xmlui/ bitstream/ handle/123456789/5610/337689.pdf? sequence $=1 \&$ isAllowed $=\mathrm{y},(\mathrm{Et}: 31.05 .2020)$.

Gümüş, Mustafa Alper. Borçlar Hukuku Özel Hükümler, C. 2, 3. Baskı, Vedat Yayıncılık, İstanbul 2014.

Gümüş, Mustafa Alper. Türk-İsviçre Borçlar Hukukunda Vekilin Özen Borcu, Beta Yayınevi, İstanbul 2001 (Özen).

Hatemi, Hüseyin/ Gökyayla, Emre. Borçlar Hukuku Genel Bölüm, 3. Baskı, Vedat Kitapç1lı, İstanbul 2015.

Hatemi, Hüseyin/ Serozan, Rona/ Arpac1, Abdülkadir. Borçlar Hukuku Özel Bölüm, Filiz Kitabevi, İstanbul 1992.

Huguenin, Claire. Obligationenrecht-Allgemeiner und Besonderer Teil, Schulthess Verlag, Zürich 2012.

İnal, H. Tamer. Tüketici Hukuku, 3. Baskı, Seçkin Yayınc1lık, Ankara 2014.

Karakocalı, Ahmet. Otomotiv Sektörü Bakımından Garanti Belgesi ve Satış Sonrası Hizmetlere İlişkin Yasal Düzenlemelerin Değerlendirilmesi, Sektörel Bazda Tüketici Hukuku ve Uygulamaları 2015-2016, Bilge Yayınevi, Ankara 2016 (Ed. TOPBAŞ, Hakan/ ÜÇIŞIK, H. Fehim), s. 146-166.

Karakocalı, Ahmet. Tüketici Hukuku Davaları, Teori-Uygulama, (Ed. Şahin Mccarthy, Oya/ Dinç, Mutlu), Seçkin Yayıncılık, Ankara 2017.

Kocayusufpaşaoğlu, Necip. Borçlar Hukukuna Giriş, Hukuki İ̧slem, Sözleşme, C. 1, 7. Tıpkı Baskı, Filiz Kitabevi, İstanbul 2017.

Korkmaz, Sezer. "Satış Sonrası Hizmetler Ve Satış Sonrası Hizmetlerin Tüketiciler Açısından Değerlendirilmesi”, https://www.mevzuatdergisi.com/2001/06a/02.htm, (Et: 19.03.2018).

Kılıçoğlu, Ahmet M. Borçlar Hukuku (Genel Hükümler), 22. Baskı, Turhan Kitabevi, Ankara 2018.

Kilıçoğlu, Ahmet M. Borçlar Hukuku Özel Hükümler, Turhan Kitabevi, Ankara 2019 (Özel).

Krüger/ Gottwald. Münchener Kommentar zum BGB, Band 3, BGB § 328, 8. Auflage, Verlag C.H. Beck, München 2019.

Kuntalp, Erden. Karışık Muhtevalı Akit, 2. Baskı, Bankacılık Enstitüsü Yayınları, Ankara 2013.

Kuntalp, Erden. Karışık Muhtevalı Akit, Ankara Üniversitesi Hukuk Fakültesi Yayınları, Ankara 1971. 
Mccarthy, Oya Şahin. "6502 sayılı Tüketicinin Korunması Hakkında Kanun Genel Çerçevesi ve 4077 sayı1ı Eski Yasa ile Kıyaslama”, İstanbul Barosu Dergisi, C. 88, Özel Say1, 2014.

Oğuzman, M. Kemal/ Öz, Turgut. Borçlar Hukuku Genel Hükümler, C. 1, Vedat Kitapçlık, İstanbul 2018.

Oğuzman, M. Kemal/ Öz, M. Turgut. Borçlar Hukuku Genel Hükümler, C. 2, 12. Baskı, Vedat Kitapçılık, İstanbul 2016.

Oktay, Saibe. "İsimsiz Sözleşmelerin Geçerliliăi, Yorumu ve Boşlukların Tamamlanması", İUHHFM., C. 55, S. 1-2, 1996, s. 263-296.

Özdemir, Şerife Gül/ Sarı, Cahide Gülnur. Tüketicinin Korunması Hukuku, Danışman Yayınevi, İstanbul 2006.

Özel, Çağlar. Tüketicinin Korunması Hukuku, 3. Baskı, Seçkin Yayınevi, Ankara 2016.

Selimoğlu, Yaşar Engin. Eser Sözleşmesi, 4. Baskı, Adalet Yayınevi, Ankara 2017.

Serozan, Rona/ Baysal, Başak/ Sanlı, Kerem Cem. Borçlar Hukuku Özel Bölüm, 4. Baskı, Oniki Levha Yayıncılık, İstanbul 2019.

Säcker, Franz Jürgen/ Rixecker, Roland/ Oetker, Hartmut/ Limperg, Bettina. Münchener Kommentar zum $B G B, 8$. Auflage, Verlag C.H. Beck, München 2020.

Säcker, Franz Jürgen/ Rixecker, Roland/ Oetker, Hartmut. Münchener Kommentar zum BGB, 7. Auflage, Verlag C.H. Beck, München 2017.

Tandoğan, Haluk. Borçlar Hukuku Özel Borç İlişkileri, C. 2, 5. Tıpkıbasım, Vedat Yayıncılık, İstanbul 2010, (Borçlar).

Tandoğan, Haluk. Türk Mesuliyet Hukuku (Akit Dlşı ve Akdi Mesuliyet), Vedat Kitapçılık, Ankara 1961, (Mesuliyet).

Tarman, Zeynep Derya. Türk Hukukunda Imalaţ̧ının Sorumluluğuna Genel Bir Bakış, http: // www. journals. istanbul. edu. tr/ iuhfm/ article/ download/ 1023003858/1023003448 (Et: 03.04.2018).

Tekinay, Selahattin Sulhi/ Akman, Serhat/ Burcuoğlu, Haluk/ Altop, Atilla. Borçlar Hukuku Genel Hükümler, 7. Bask1, Filiz Kitabevi, İstanbul 1993.

Tiryaki, Betül. Tüketicinin Korunması Hukuku Açısından Aylplı Hizmetten Doğan Sorumluluk, https: // tez. yok. gov. tr/ UlusalTezMerkezi/ tezSorguSonucYeni. jsp, (Et: 02.03.2018).

Tunçomağ, Kenan. Türk Borçlar Hukuku, Genel Hükümler, C. 1, Sermet Matbaası, İstanbul 1968.

Türkmen, Ahmet. "Tüketici İşlemlerinde Ayıplı Mal ve Hizmetten Doğan Seçimlik Hakların Tabi Olduğu Zamanaşımı ve Bunun Garanti Taahhütleriyle İlişkisi”, Dokuz Eylül Üniversitesi Hukuk Fakültesi Dergisi, C. 16, Özel Sayı 2014, s. 3389-3448, 2015.

Uyumaz, Alper. Yetkili Servis Sözleşmesi, Oniki Levha Yayınları, İstanbul 2018.

Üstün, Zübeyde Meltem, Türk ve Avrupa Birliği Tüketici Hukukunda İmalatçının Hukuki Sorumluluğu, http://dspace.deu. edu.tr/xmlui/handle/12345/11566 (Et: 23.03.2018).

von Tuhr, Andreas. Borçlar Hukukunun Umumi Kısmı, C. 1-2, Yargıtay Yayınları, Ankara 1983 (Çev: Cevat Edege).

Yavuz, Cevdet/ Acar, Faruk/ Özen, Burak. Borçlar Hukuku Dersleri Özel Hükümler, Beta Yayınevi, 13. Baskı, İstanbul 2014.

Yavuz, Cevdet/ Acar, Faruk/ Özen, Burak. Türk Borçlar Hukuku Özel Hükümler, Beta Yayınevi, İstanbul 2014. Zevkliler, Aydın/ Gökyayla, Emre. Borçlar Hukuku Özel Borç İlişkileri, 18. Baskı, Turhan Kitabevi, Ankara 2018. 